\title{
Eocene, Oligocene, and Miocene Rocks and Vertebrate Fossils at the Emerald Lake \\ Locality, 3 Miles South of Yellowstone National Park, Wyoming
}

GEOLOGICALSURVEY PROFESSIONAL PAPER 932-A

Prepared in cooperation with the Geological Survey of Wyoming, the Department of Geology of the University of Wyoming, the American Museum of Natural History, and the Carnegie Museum

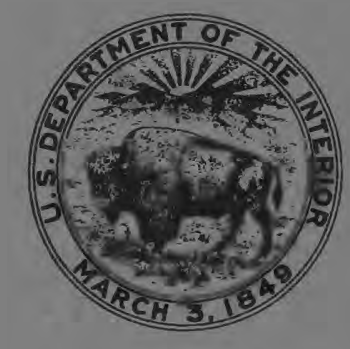




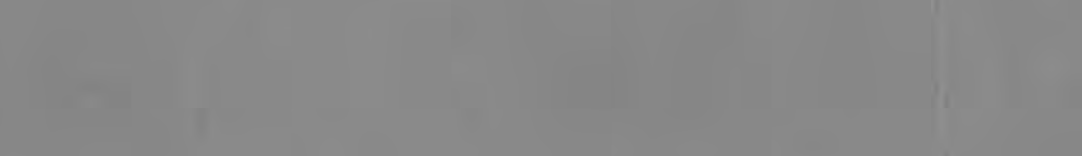

两

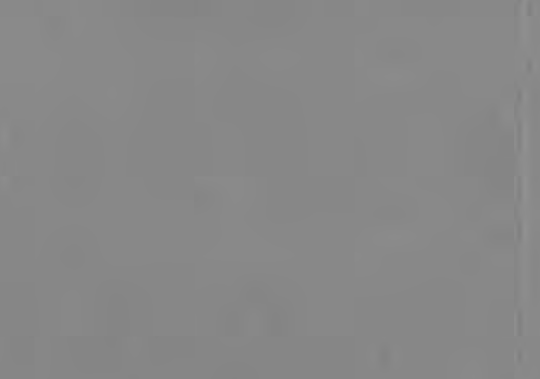

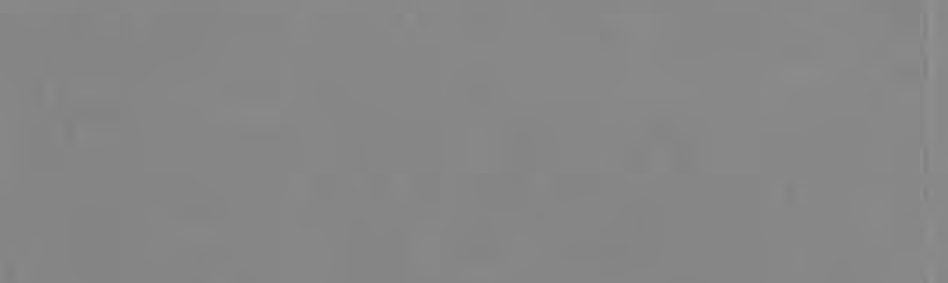

(1)

If 14

(1)

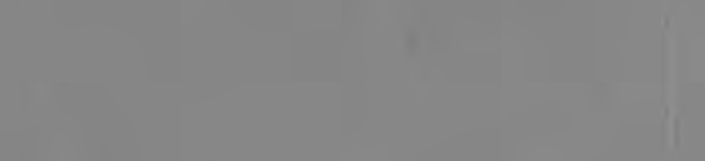

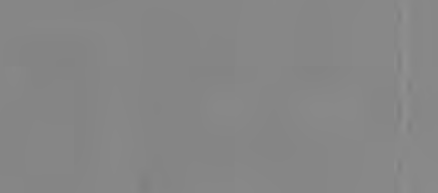

118

(1)

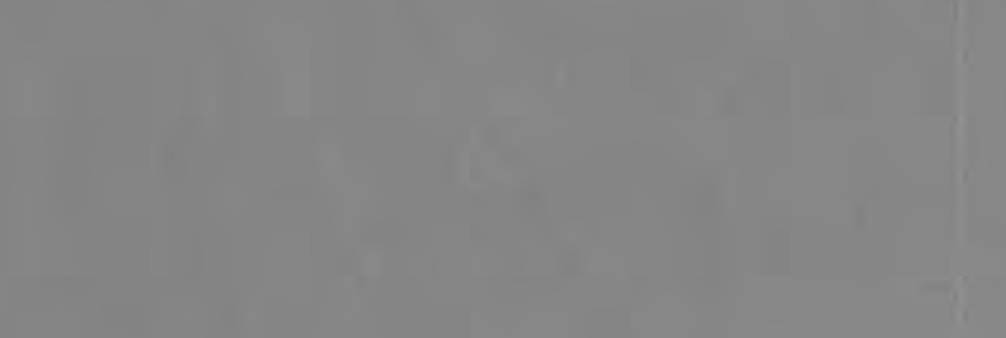

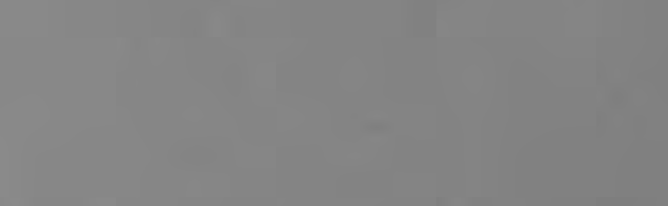

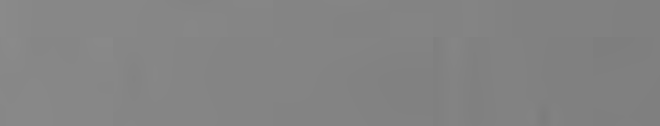

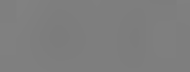

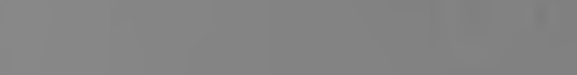

$1=$

1,4

(I)

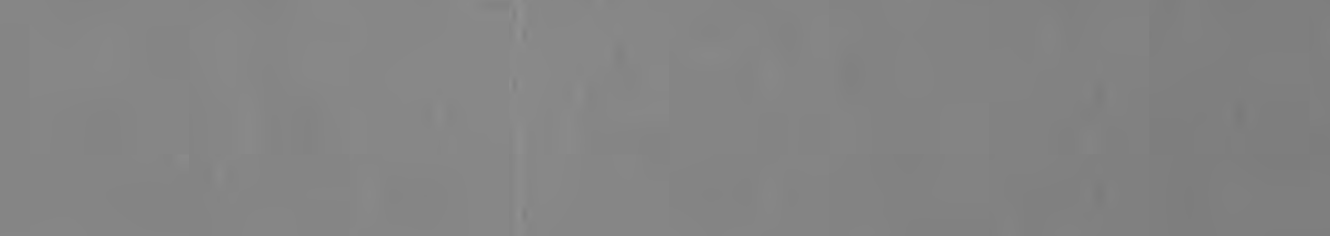

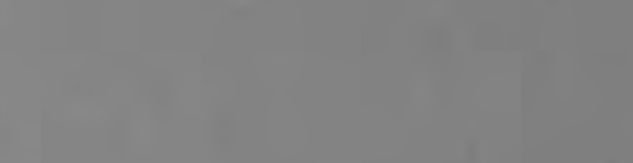

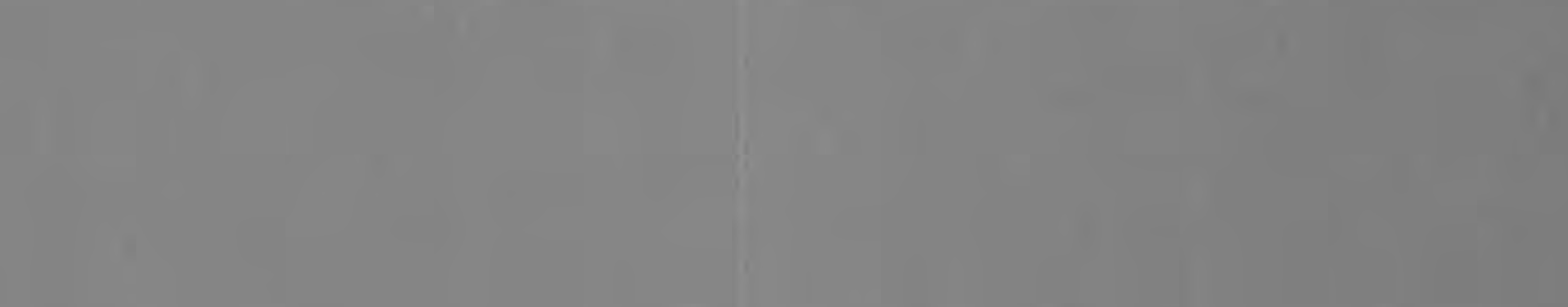

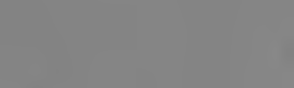

Sili
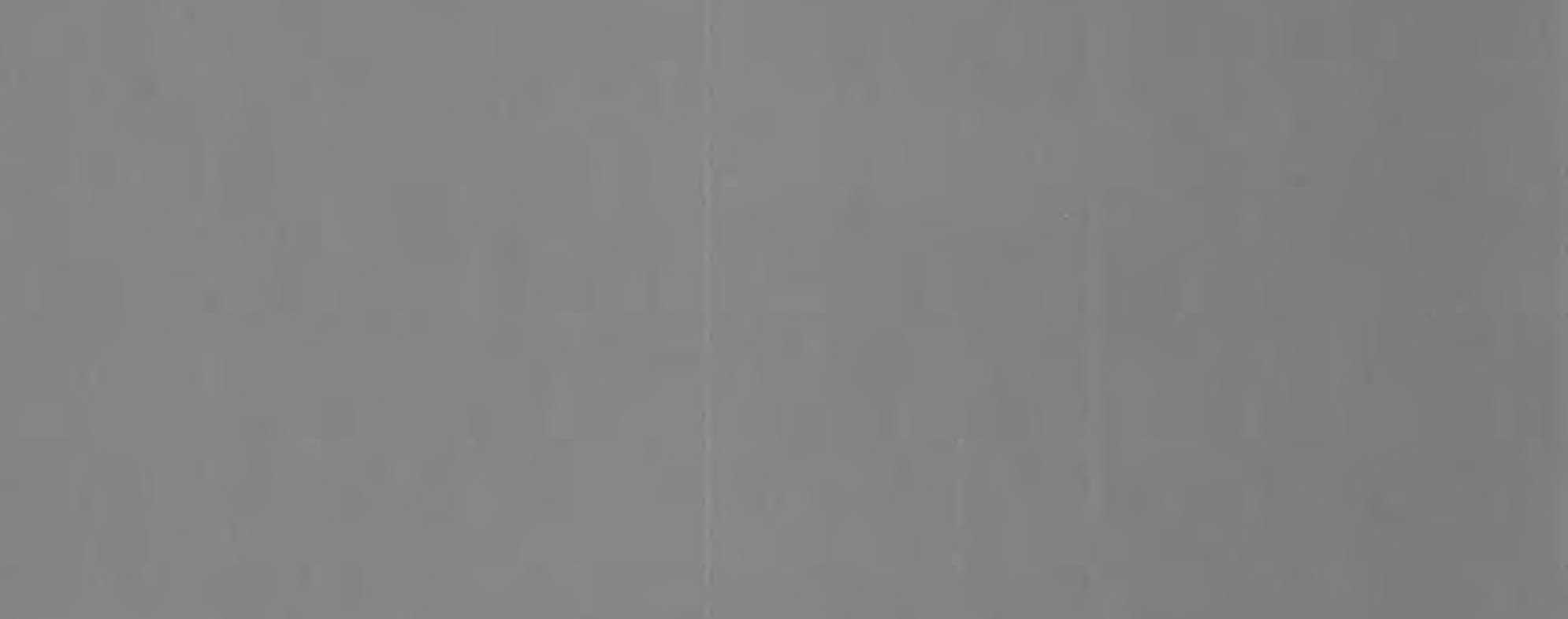

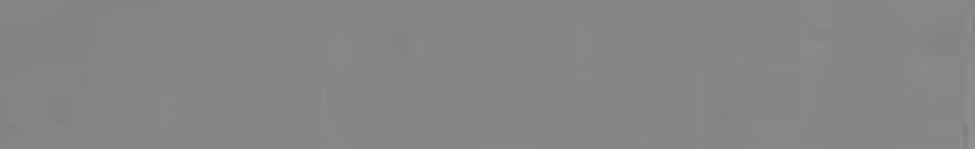




\section{Eocene, Oligocene, and Miocene Rocks and Vertebrate Fossils at the Emerald Lake Locality, 3 Miles South of Yellowstone National Park, Wyoming}

By J. D. LOVE, MALCOLM C. McKENNA, and MARY R. DAWSON

GEOLOGY OF THE TETON-JAGKSON HOLE REGION, NORTHWESTERN WYOMING

GEOLOGICAL SURVEY PROFESSIONAL PAPER 932-A

Prepared in cooperation with the Geological Survey of Wyoming, the Department of Geology of the University of Wyoming, the American Museum of Natural History, and the Carnegie Museum

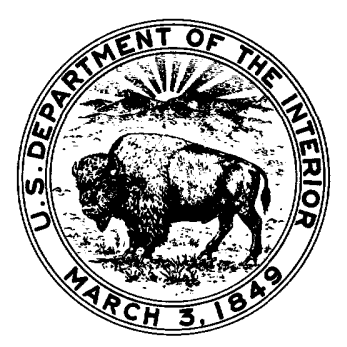


UNITED STATES DEPARTMENT OF THE INTERIOR

THOMAS S. KLEPPE, Secretary

GEOLOGICAL SURVEY

V. E. McKelvey, Director

Library of Congress Cataloging in Publication Data

Love, John David, 1913-

Eocene, Oligocene, and Miocene rocks and vertebrate fossils at the Emerald Lake locality, 3 miles south of Yellowstone National Park, Wyoming.

(Geology of the Teton-Jackson Hole region, northwestern Wyoming) (Geological Survey Professional Paper 932-A)

Bibliography: p.

Includes index.

1. Geology, Stratigraphic-Tertiary. 2. Vertebrates, Fossil. 3. Geology-Wyoming-Teton Co.

I. McKenna, Malcolm C., joint author. II. Dawson, Mary R., joint author. III. Wyoming Geological Survey. IV. Title:

Eocene, Oligocene, and Miocene rocks and vertebrate fossils at the Emerald Lake locality... V. Series. VI. Series:

United States Geological Survey Professional Paper 932-A.

QE691.L79 $\quad 551.7^{\prime} 8 \quad 76-8159$

For sale by the Superintendent of Documents, U.S. Government Printing Office

Washington, D.C. 20402

Stock Number 024-001-02792-5 


\section{CONTENTS}

Metric-English equivalents.

Abstract .....

Introduction....

Acknowledgments

Wiggins Formation (Eocene)

White River Formation (Oligocene)

Colter Formation (Miocene)
Page

IV | Post-Miocene rocks...

Pyroxene andesite and basalt of Emerald Lake.................... 21

1 Huckleberry Ridge Tuff ....................................................... 22

2 Structural summary .................................................................

2 References cited................................................................. 25

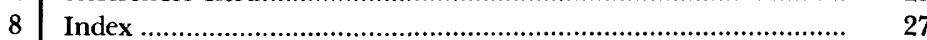
(1)

2

5

\section{ILLUSTRATIONS}

FIGURE 1. Map showing mountains, basins, and volcanic areas in and adjacent to northwestern Wyoming...

2. Relief map...

3. Geologic map..

4-9. Photographs:

4. Volcanic conglomerate in the Wiggins Formation, measured section A

5. Volcanic conglomerate in the Wiggins Formation, measured section D

6. Measured section $\mathrm{C}$ of the White River Formation

7. Measured section $\mathrm{D}$ of the White River Formation

8. View north from measured section $D$, showing the White River and Wiggins Formations

9. Detail of lithology of the White River Formation

10. Graph showing semiquantitative spectrographic analyses

11. Diagram showing relations between the Wiggins and White River Formations.

12. Schematic diagram showing relations of Tertiary and older rocks .

13-18. Photographs:

13. Vertical aerial photograph showing Oligocene and Miocene vertebrate fossil sites

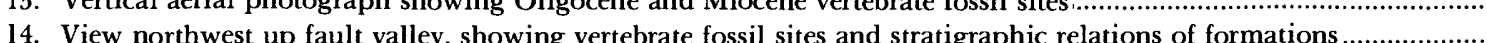

15. Colter Formation at locality SR.

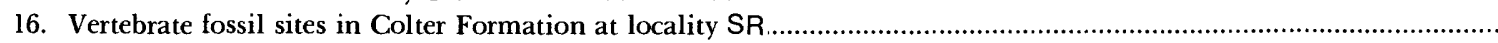

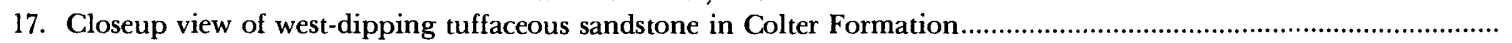

18. Right lower jaw of undescribed aplodontid rodent.

\section{TABLES}

TABLE 1. Rock analyses of tuffaceous strata of early Oligocene and Miocene age in the Emerald Lake, Granite Mountains, and Beaver Divide areas, Wyoming, and Black Butte, Montana.

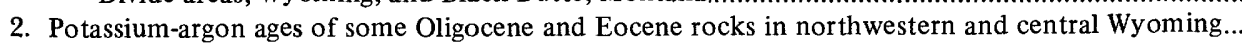

3. Distribution by site of Oligocene and Miocene fossils at Emerald Lake locality ..... 
METRIC-ENGLISH EQUIVALENTS

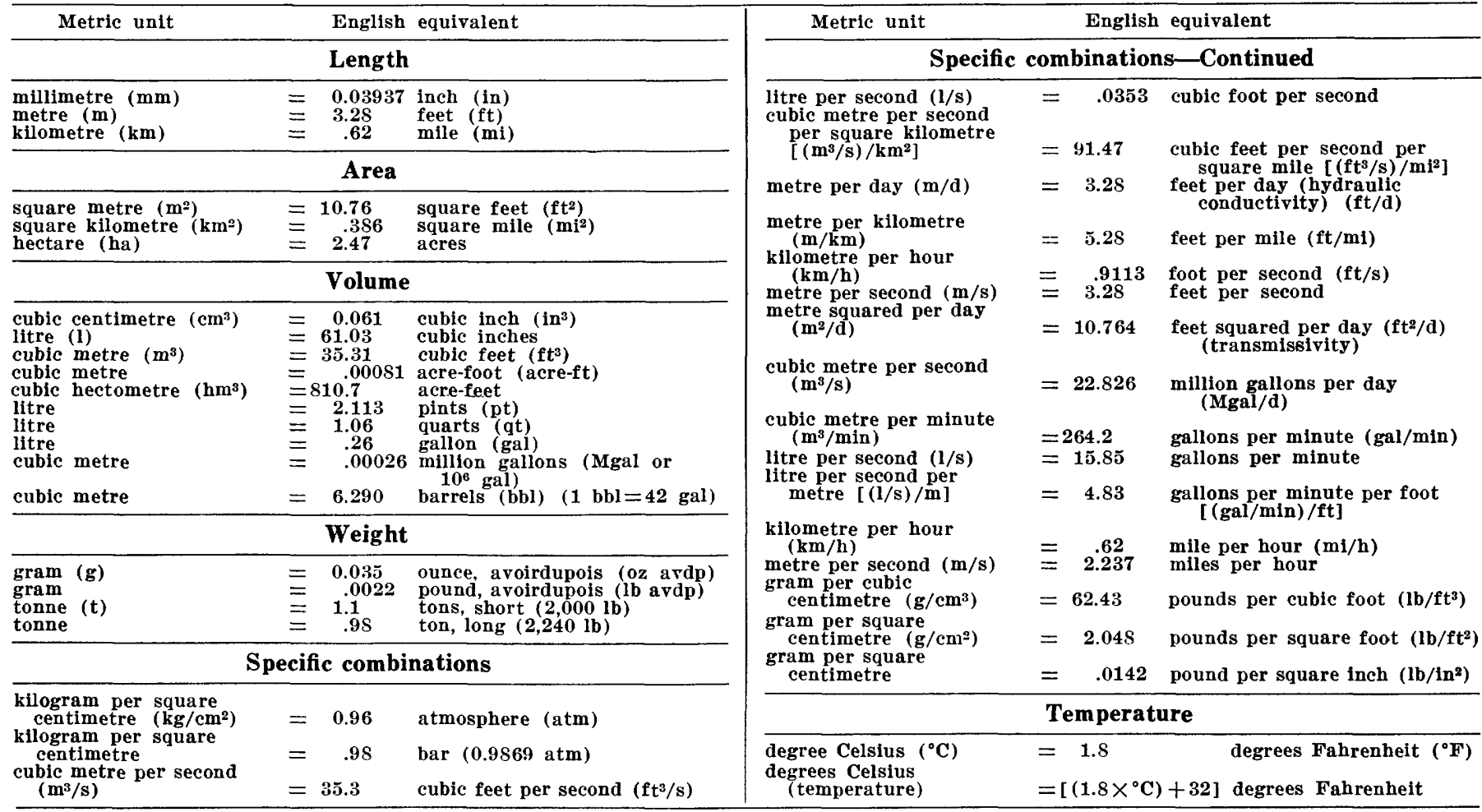




\title{
EOCENE, OLIGOCENE, AND MIOCENE ROCKS AND VERTEBRATE FOSSILS AT THE EMERALD LAKE LOCALITY, 3 MILES SOUTH OF YELLOWSTONE NATIONAL PARK, WYOMING
}

\author{
By J. D. Love, Malcolm C. MaKenna, ${ }^{1}$ and Mary R. Dawson ${ }^{2}$
}

\begin{abstract}
Several small remnants of Oligocene and Miocene rocks, partly channel deposits, containing diagnostic vertebrate fossils were preserved by late Cenozoic downfaulting in the Emerald Lake area, 3 miles (4.8 kilometres) south of Yellowstone National Park. Inasmuch as no Oligocene or Miocene rocks are at present recognized in Yellowstone National Park, the Emerald Lake locality provides a clue as to sedimentation and environment along the south boundary of the park during these epochs.

Equally important are newly reported potassium-argon ages that show the Wiggins Formation, long thought to be of Oligocene age, to be Eocene. A review of the stratigraphic relations determined that the Oligocene White River Formation was deposited in channels cut in the mafic volcanic conglomerates of the Wiggins, rather than being a finegrained facies intertonguing laterally with the conglomerates. The source of the volcanic debris in the Wiggins was vents in the Absaroka Range east and northeast of Emerald Lake. More than 1,000 feet (300 metres) of the Wiggins Formation was removed by erosion prior to deposition of the White River Formation.
\end{abstract}

The White River Formation consists of 100 feet ( 30 metres) or more of white tuff and claystone, probably derived from distant sources to the west, northwest, or southwest. The assemblage of 16 species of mammals in these strata is of early Oligocene age (Chadronian provincial age) and is the same as that found in similar strata on the high plains of Nebraska. Therefore, despite the adjacent mountainous terrain, the environmental conditions in the Emerald Lake area are assumed not to have been appreciably different from those on the nonmountainous plains. A potassium-argon age on biotite from the fossiliferous beds is 35.8 million years.

Unconformably overlying the White River is the Colter Formation, possibly 900 feet (275 metres) thick in the Emerald Lake area, consisting of soft gray tuffaceous sandstone that contains vertebrate fossils of early Miocene age (Arikareean provincial age). Again, these fossils are the same forms that occur in rocks of similar age in eastern $W$ yoming and western Nebraska.

Pyroxene andesite and basalt, with a potassium-argon age of 2.19 million years, and rhyolitic tuff, the Huckleberry Ridge Tuff, dated elsewhere as 2 million years, are the youngest rocks in the area. They provide data on timing of the most recent tectonic events.

'The American Museum of Natural History, New York, N.Y.

${ }^{2}$ Carnegie Museum, Pittsburgh, Pa.

\section{INTRODUCTION}

No Oligocene or Miocene rocks are at present recognized in Yellowstone National Park and, except for the Emerald Lake locality (Love, 1956b) and other localities to the south in Jackson Hole, no rocks of unquestioned Oligocene or Miocene age have been described from the entire Yellowstone-Absaroka volcanic field (figs. 1, 2). The Emerald Lake locality includes outcrops of two formations-one that has yielded Oligocene vertebrate fossils and the other, Miocene. The locality is named after Emerald Lake (fig. 3), which is about 1 mile $(1.6 \mathrm{~km})$ south of the fossil sites, in the southeastern part of the Mount Hancock 15-minute quadrangle, Teton County. Figures 2 and 3 show the geographic setting, topography, and relief.

The geology of the Emerald Lake locality was first mapped by Hague (1904, Lake 30-minute quadrangle). He classified the Tertiary rocks as "late basic breccia" and considered them to be of Miocene age (the term "Oligocene" was not used in this region at that time). Iddings (in Hague and others, 1899, p. 298-300) described the "late basic breccia" of this general area as consisting of a basal sequence, 1,000 feet $(300 \mathrm{~m})$ thick, of water-laid pyroxene andesite debris that contains beds and lenses of light-colored tuff with biotite and sanidine phenocrysts, overlain by $1,000(300 \mathrm{~m})$ feet of "true breccia without waterlaid layers."

White tuffaceous badlands in the Emerald Lake locality were first noted by Love during a reconnaissance in 1945; in 1948 a search for vertebrate fossils was made, and a small assemblage was obtained. It was identified as early Oligocene (Chadronian provincial age) by the late $\mathbf{M}$. J. Hough (written commun., Jan. 5, 1950; Love, 1952, p. 19). Additional fossils were collected in 1953 by Love at the same locality (M. J. Hough, written commun., Dec. 18, 1953; Love, 1956b). 


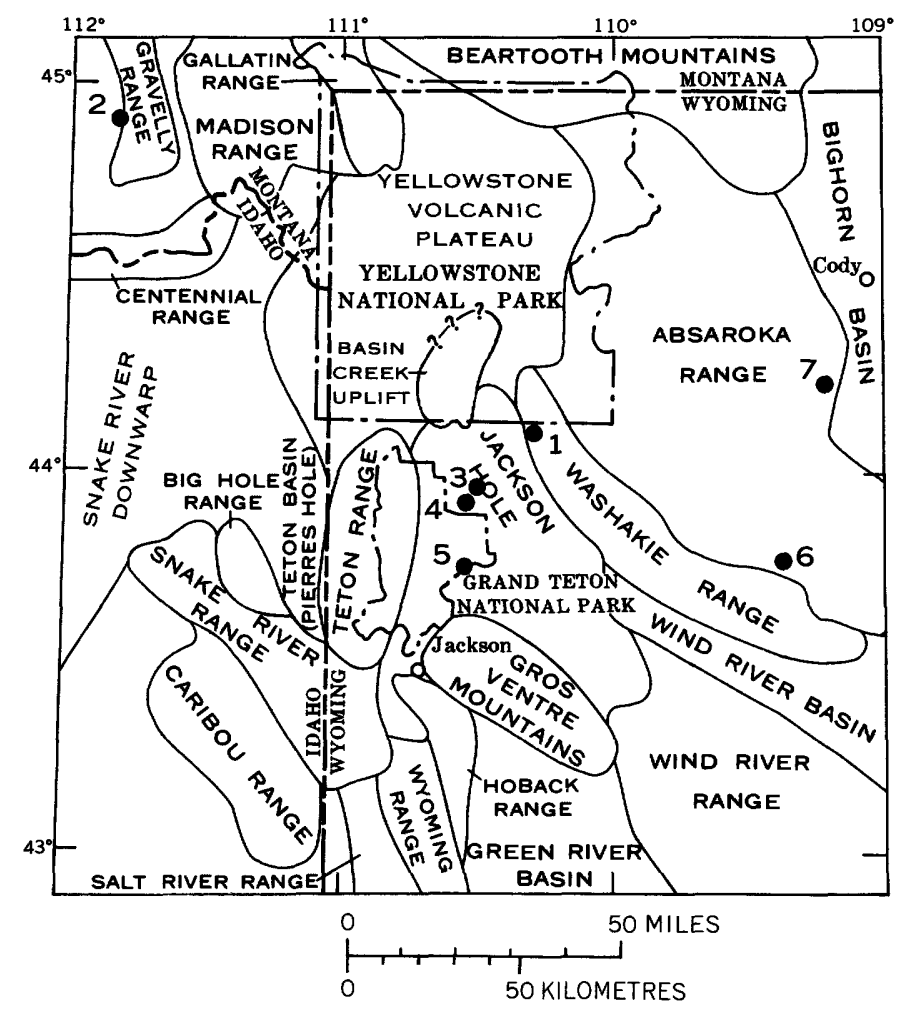

FIGURE 1.-Mountains, basins, and major volcanic areas in and adjacent to northwestern Wyoming. Localities indicated by numbers are as follows: 1, Emerald Lake locality of Oligocene (White River Formation) and Miocene (Colter Formation) rocks; 2, White River Formation on Gravelly Range; 3, White River Formation on Pilgrim Creek; 4, type locality of Colter Formation; 5, Cunningham Hill fossil locality in Colter Formation; 6, site of principal reference section of Wiggins Formation; 7, Carter Mountain locality of Wiggins Formation.

While trying to check on the anomalous occurrence reported by Hough in these collections of Teleodus uintensis (Duchesnean provincial, or late Eocene, age elsewhere) and Ischyromys aff. I. pliacus ( $=$ I. typus, Orellan provincial, or middle Oligocene, age elsewhere), McKenna discovered in 1964 that only one of the specimens could be found at the National Museum of Natural History where they had been studied by Hough. It was then decided to make still another collection from the Emerald Lake locality, and this was accomplished in August 1964. The new collection, and additional ones made in 1969 and 1971, confirmed the early Oligocene (Chadronian) age of the Emerald Lake assemblage and produced no evidence of Teleodus uintensis or Ischyromys typus.

These Oligocene white tuffaceous rocks were included in the Wiggins Formation in the geologic map of Teton County (Love, 1956c) and for many years were thought to be a part of that formation. However, potassium-argon dates from the Wiggins indicated that these rocks were of Eocene age. (See discussion of the age of the Wiggins
Formation.) This finding prompted a reexamination, in 1969 and 1971, of the field relations of the vertebratebearing white Oligocene strata to the adjacent Wiggins Formation.

John F. Sutton, in 1971, discovered a new vertebrate fossil locality that led to the identification, on the basis of rock-stratigraphic criteria, of a hitherto unrecognized remnant of the White River Formation 16 miles $(26 \mathrm{~km})$ southwest of Emerald Lake (fig. 1, loc. 3; Sutton and Black, 1972).

Volcaniclastic rocks in the type locality of the Colter Formation, 18-20 miles (29-32 km) southwest of Emerald Lake (fig. 1, loc. 4) have yielded Miocene vertebrate fossils. Additional localities of Miocene strata and vertebrate fossils are known still farther south (fig. 1, loc. 5; Love, 1956a, 1973; Black, 1968b; Sutton and Black, 1972).

\section{ACKNOWLEDGMENTS}

Many persons have helped us during the 28 years of intermittent study of these rocks. J. L. Weitz, R. K. Hose, and S. O. Reynolds helped make the collections of vertebrate fossils in 1948. M. J. Hough identified the faunules collected in 1948 and 1953. Chemical and spectrographic analyses were made in the laboratories of the U.S. Geological Survey. Emil and Larry Feuz provided efficient and ingenious assistance far beyond their duties as packers. For help on many other facets of this study we are grateful to Morris F. Skinner, Beryl E. Taylor, Ted Galusha, Richard H. Tedford, Craig C. and Connie Black, Margaret S. Stevens, Robert M. Hunt, Donald Rasmussen, and the late Childs Frick. John F. Sutton provided data on his Oligocene discovery farther southwest in Jackson Hole.

We are especially grateful to $\mathrm{H}$. W. Smedes, J. D. Obradovich, and W. L. Rohrer for their persistent challenging of field observations. Their frank discussions, plus the several potassium-argon age determinations by Obradovich from samples which they collected, were of major value in shaping what we believe to be a valid reconstruction of the geology of the Emerald Lake area.

This study was prepared with the cooperation of Robert S. Houston, Chairman, Department of Geology, University of Wyoming, D. L. Blackstone, Jr., former State Geologist of Wyoming, and D. N. Miller, present State Geologist. We are also indebted to Professor Houston for most of the petrographic work on our rock samples from this area.

\section{WIGGINS FORMATION (EOCENE)}

The Wiggins Formation is described in some detail because (1) most previous publications call it Oligocene or Oligocene(?), and (2) until recently it had been thought to intertongue with Oligocene vertebrate-bearing strata. It underlies and surrounds on three sides the Oligocene rocks of the Emerald Lake area (fig. 3), and, in addition, it con- 
$110^{\circ}$

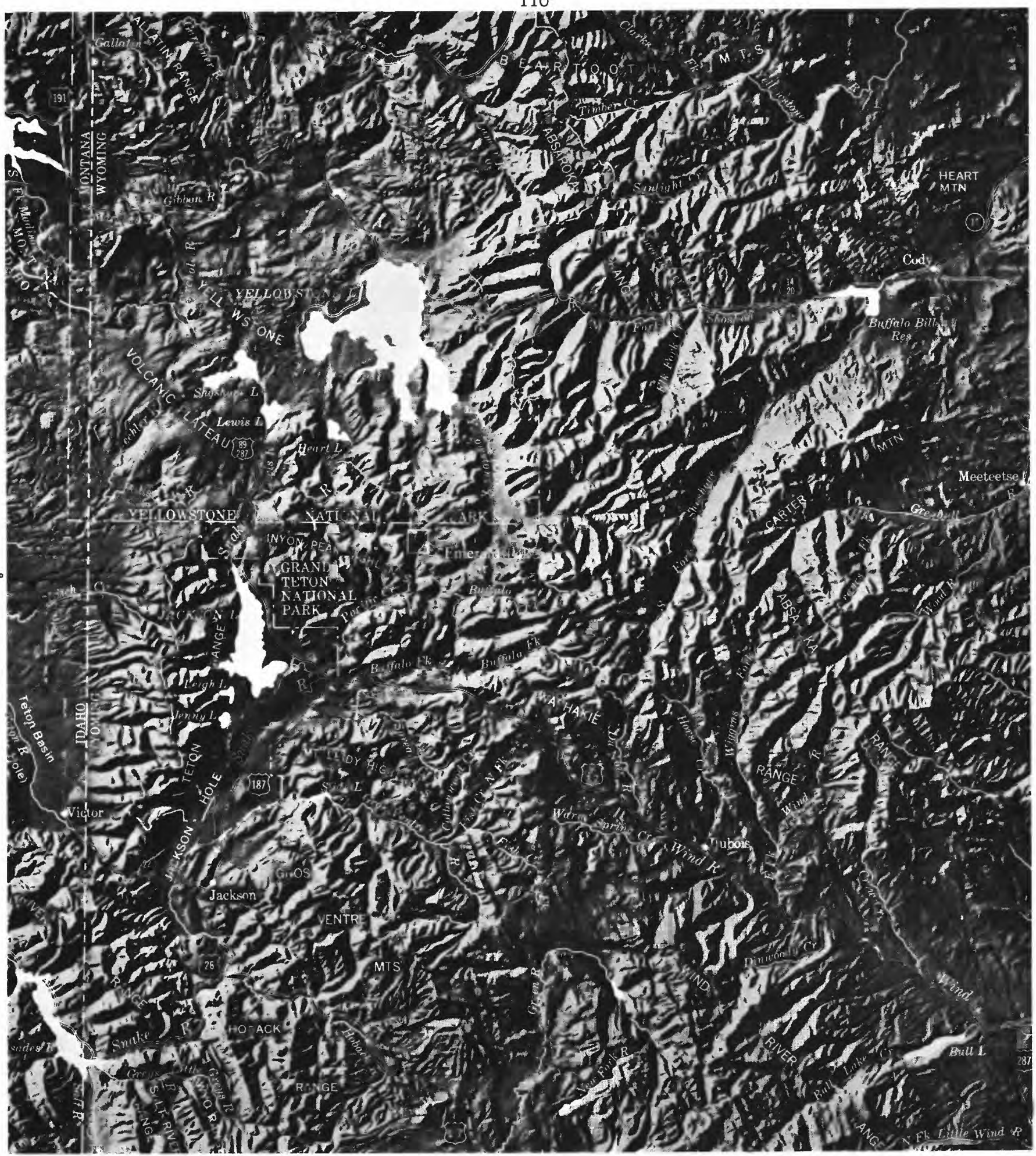

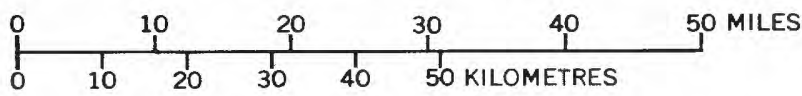

Figure 2.-Relation of Emerald Lake area to mountains, basins, and volcanic areas in northwestern Wyoming.

tributed coarse rock debris to the Oligocene strata. The $\mid$ gray boulder conglomerates $($ fig. 4,5$)$ that are water-laid Wiggins Formation consists of very coarse brown to dark- $\mid$ and crudely stratified. Details of lithology are given in the 


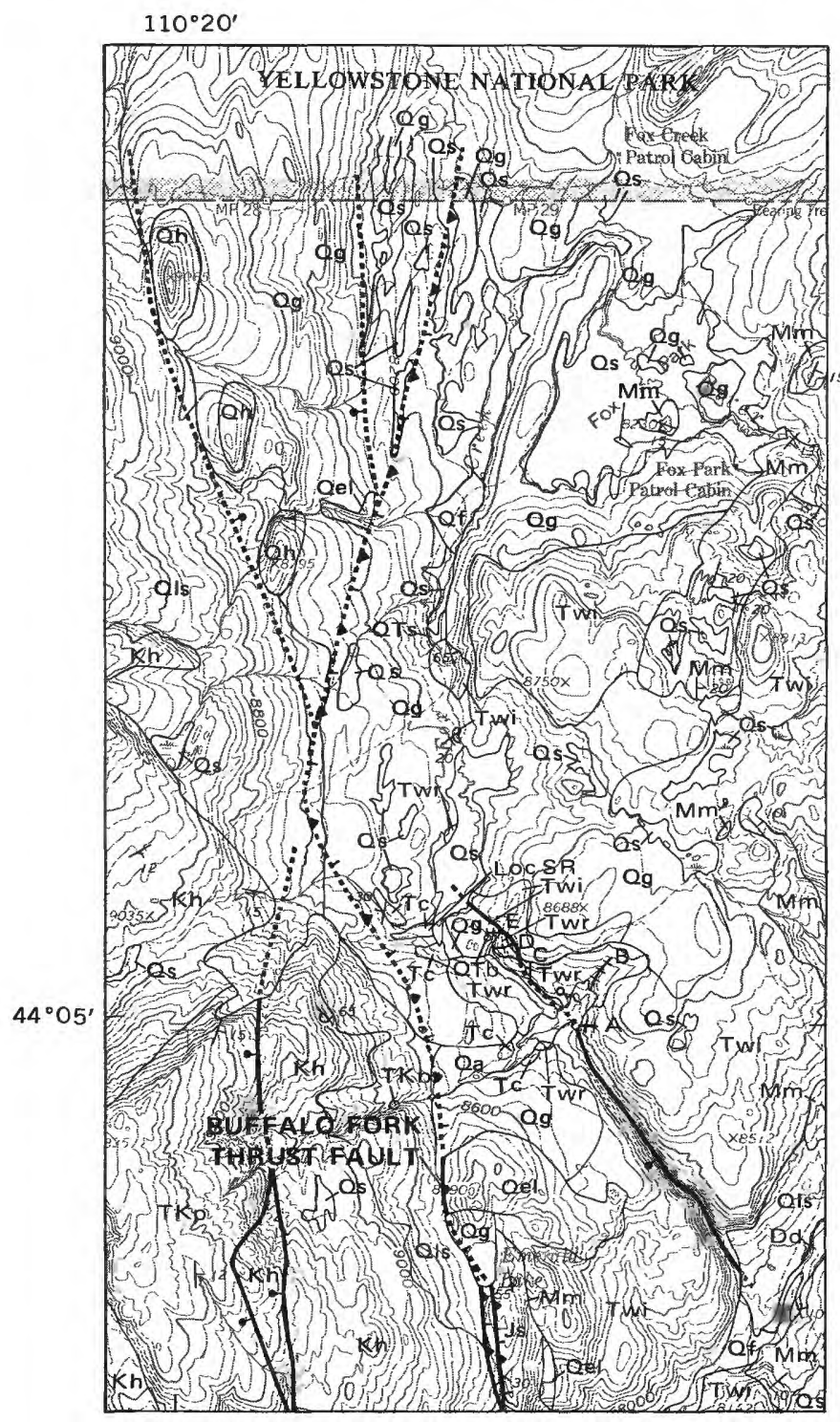

\section{CORRELATION OF MAP UNITS}
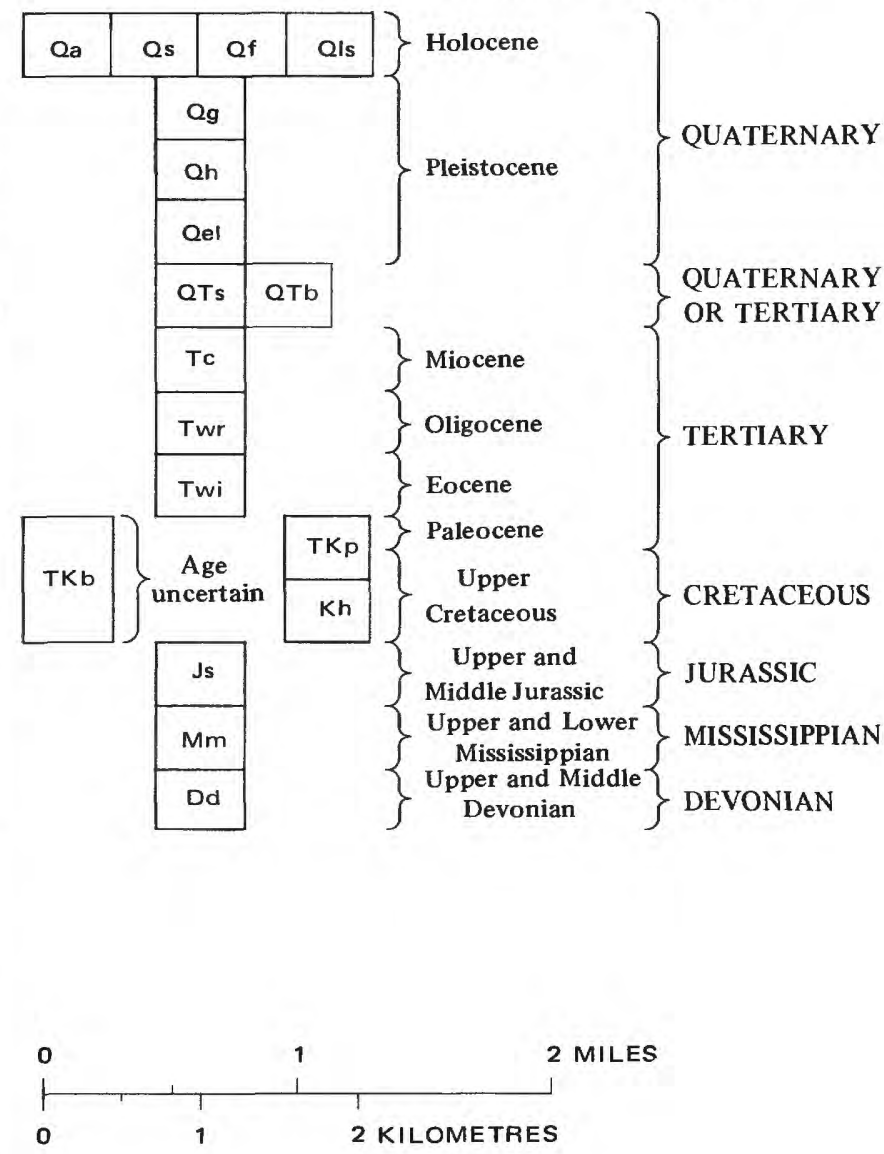

Figure 3 (above and facing page).-Emerald Lake area. Geology by J. D. Love, 1948, 1953, 1964, 1969, 1971. Base from U.S. Geological Survey Mount Hancock topographic quadrangle, 1959.

measured sections. A vividly graphic description of the "late basic breccia" which includes much of the Wiggins Formation 5-10 miles (8-16 km) southeast of the Emerald Lake area was written by Iddings (in Hague and others, 1899 , p. 299). A modern discussion and classification of these volcaniclastic rocks is presented by Smedes and Prostka (1972).

Extensive outcrops, as much as 400 feet $(120 \mathrm{~m})$ thick, of the lower part of the Wiggins Formation are present in the straight fault-line canyon east of Emerald Lake (figs. 3, 13). Here, for more than a mile, vertical faces of the conglomerate are continuously exposed, and the sedimentary structures can be seen. The conglomerate consists of rounded to angular boulders, as much as 5 feet $(1.5 \mathrm{~m})$ in diameter, of red, gray, and black andesite porphyry and red, green, and black basalt jumbled in with a mass of crystal and lithic coarse-grained gray tuff. Crude, nearly horizontal, bedding is visible from a distance but is inconspicuous at close range. There is little clay and silt-size sediment in this facies. The finest grained debris is a conspicuous channel deposit, 5 feet $(1.5 \mathrm{~m})$ thick, of bedded volcanic sandstone and angular pea gravel exposed at the bottom of the canyon about one-half mile $(1 \mathrm{~km})$ downstream from its head.

For about 100 yards $(90 \mathrm{~m})$ along the bottom of the canyon at the southern end of the slight kink (fig. 3), embedded in the boulder conglomerate, are abundant green, brown, and gray silicified (but not agatized) moderately well preserved waterworn wood fragments as much as 1 foot $(0.3 \mathrm{~m})$ or more in diameter in horizontal posi- 


\section{DESCRIPTION OF MAP UNITS}

\begin{tabular}{|l|}
\hline Qa \\
\hline Qs \\
\hline Qf \\
\hline Qls \\
\hline
\end{tabular}

Qg

Qh
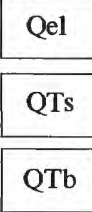

Tc

Twr

Twi

TKp

$\mathrm{TKb}$

$\mathrm{Kh}$

Js

$\mathrm{Mm}$

Dd
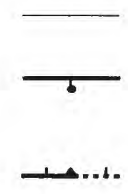

THRUST-NORMAL FAULT - Dashed where approximately located; dotted where concealed. Sawteeth on upper plate; hachures on downthrown side of younger normal fault along approximate trace of older thrust fault

STRIKE AND DIP OF BEDS

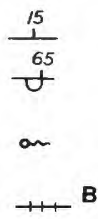

Inclined

Overturned

SPRING ANALYZED FOR URANIUM

B

Loc SR

ALLUVIUM (HOLOCENE) - Gravel, sand, and silt; alluvium in forest-covered areas not mapped

FLOOD-PLAIN DEPOSITS (HOLOCENE) - Stratified sand and gravel along major streams downslope trending ridges and valleys crysts. Thickness about 250 feet $(75 \mathrm{~m})$ massive. Basalt is black to dark green; some may be older or younger than andesite $(15.2 \mathrm{~m})$

BASALT (QUATERNARY OR TERTIARY) - Red and black Thickness perhaps 900 feet $(275 \mathrm{~m})$ $(30 \mathrm{~m})$ and basalt boulders. Thickness $>700$ feet $(210 \mathrm{~m})$ consists chiefly of quartzite roundstones. Thickness $>1,200$ feet $(365 \mathrm{~m})$ landslide block to hard; claystone is brittle to plastic; sandstone is brittle. Thickness $>3,000$ feet $(910 \mathrm{~m})$ Fickness unknown dolomitic shale and siltstone. Thickness uncertain

\section{CONTACT}

FULT - Dashed where approximately located; dotted where concealed. Bar and ball on downthrown side

\section{LINE OF MEASURED SECTION DESCRIBED IN TEXT}

\section{VERTEBRATE FOSSIL LOCALITY SHOWN IN FIGURE 13}

SWAMP DEPOSITS (HOLOCENE) - Clay, silt, and fine sand, dark-gray and brown; rich in vegetal debris

LANDSLIDE DEBRIS (HOLOCENE) - Chaotically mixed boulders and finer grained rock debris emplaced by mass movement

GLACIAL DEBRIS (PLEISTOCENE) - Large and small erratics mixed with gravel, sand, and silt; in places in the form of south-

HUCKLEBERRY RIDGE TUFF (PLEISTOCENE) - Rhyolite welded tuff, pink to brown; containing conspicuous quartz pheno-

PYROXENE ANDESITE AND BASALT OF EMERALD LAKE (PLEISTOCENE) - Most andesite is gray to brown, slabby to

SCORIA (QUATERNARY OR TERTIARY) - Dull-orange, pebbly; dark-brown mafic conglomerate at base. Thickness 50 feet

COLTER FORMATION (MIOCENE) - Sandstone, light-gray, tuffaceous, soft, poorly cemented, massive to poorly bedded.

WHITE RIVER FORMATION (OLIGOCENE) - Claystone, siltstone, and tuff, white, massive, brittle. Thickness $>100$ feet

WIGGINS FORMATION (EOCENE) - Volcanic conglomerate, brown and gray, water-laid; consisting chiefly of mafic andesite

INYON CONGLOMERATE (PALEOCENE AND UPPER CRETACEOUS) - Conglomerate and sandstone, brown; conglomerate

BASALT (TERTIARY OR CRETACEOUS) - Dark-green to black; interlayered with, or intruded into Harebell Formation in

HAREBELL FORMATION (UPPER CRETACEOUS) - Sandstone, siltstone, and claystone, dull-green to brown to black, soft

NCE FORMATION (UPPER AND MIDDLE JURASSIC) - Shale, red and gray, soft, and gray limestone. Faulted at

MADISON LIMESTONE (UPPER AND LOWER MISSISSIPPIAN) - Limestone, blue-gray; interbedded with gray dolomite and ragged gray to brown chert beds; red to gray sandstone and shale near top. No complete section present; thickness uncertain ARBY FORMATION (UPPER AND MIDDLE DEVONIAN) - Dolomite, dark-brown to gray; interbedded with green to yellow

tion. None was observed here in a vertical rooted position, but rooted stumps are present in similar conglomerate about 2 miles $(3 \mathrm{~km})$ to the south, on the east side of Mink Creek canyon.
Petrographic studies of the 1948 and 1953 samples, collected by Love from the Wiggins Formation at the Emerald Lake locality, were made by Houston (1964, called Mink Creek locality in his paper) and compared 


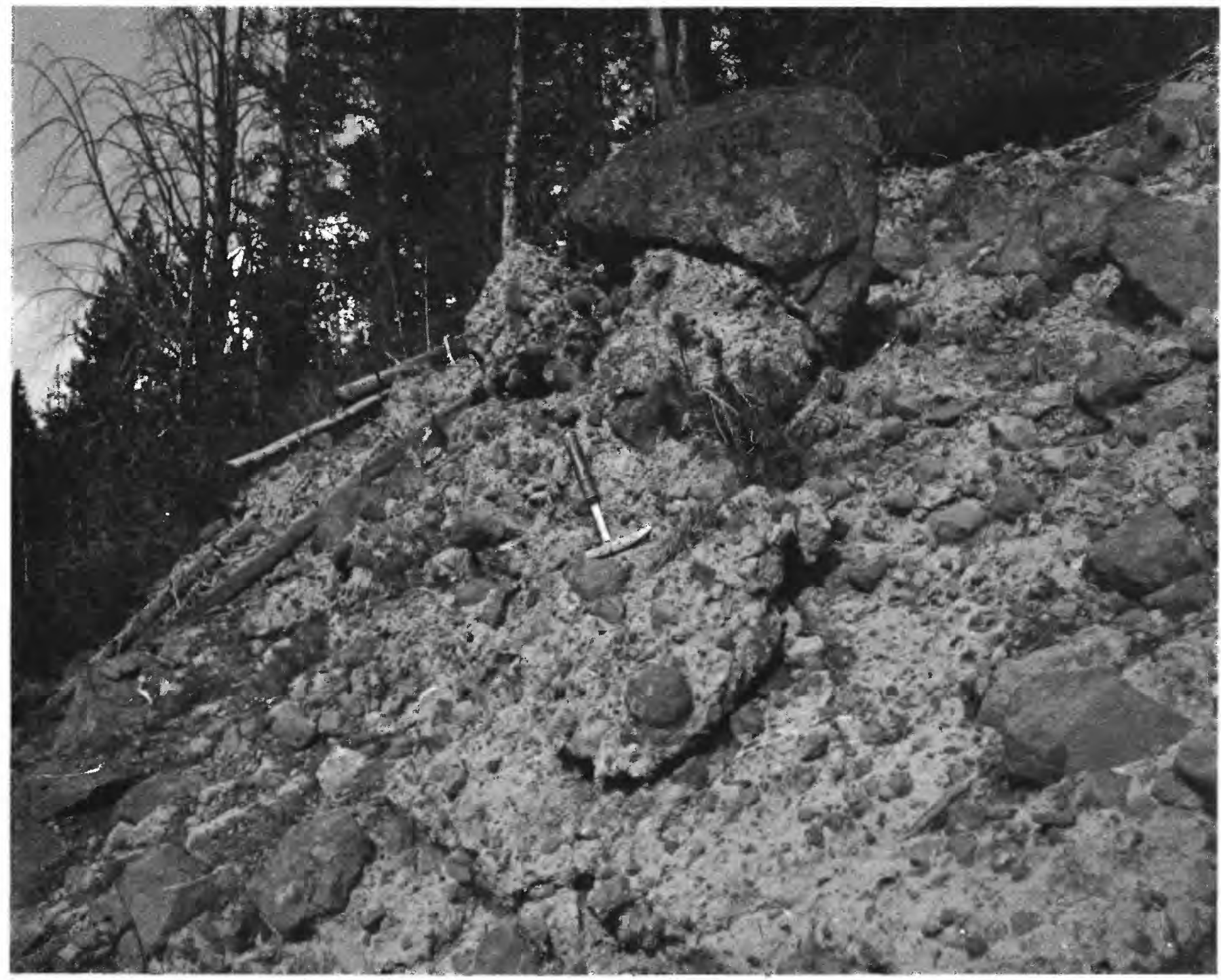

FIGURE 4.-Volcanic conglomerate in Wiggins Formation, unit 3 in measured section A. Most boulders are of red, black, and gray pyroxene andesite and basalt. Note random size and orientation of boulders and absence of bedding. Photograph by J. D. Love, Sept. 3, 1953.

with other Cenozoic rocks in Wyoming. The following data summarized his interpretation of 15 thin sections, chiefly of the volcanic conglomerate facies. Rock fragments: Very common are pyroxene andesite and basalt with glassy groundmass; common are hornblende andesite and olivine basalt; rare are obsidian, pumice, andesite, hornblende basalt, and basalt. Mineral fragments considered to be volcanic phenocryst minerals: Abundant plagioclase with average composition of $\mathrm{An}^{57}$, with range from $\mathrm{An}^{45}$ to $\mathrm{An}^{68}$; also abundant is orthopyroxene; redbrown biotite, amphibole, oxyhornblende, clinopyroxene with low $2 \boldsymbol{V}$, olivine, and magnetite are very common; and quartz is common.

In the Emerald Lake area the Wiggins Formation is estimated to be $600-800$ feet $(180-240 \mathrm{~m})$ thick. It was deposited on a surface of mountainous relief cut in Paleozoic rocks of the Washakie Range. There is about 450 feet $(140 \mathrm{~m})$ of relief along this eastern contact north of the canyon mouth shown in figure 3 . The size of the boulders (figs. 4,5 ) suggests that streams with high gradients and large volumes of water were involved. The actual conditions and mechanics of deposition, however, may not be that simple, as is indicated by a regional review of the Wiggins Formation.

Volcanic conglomerates similar to those in the Emerald Lake area are characteristic of the Wiggins all the way to Steamboat Rock, the locality of the original published section (Love, 1939; here designated the principal reference section; fig. 1 , loc. 6$)$, a distance of 50 miles $(80 \mathrm{~km})$. They have been described as "mudflows" (Ketner and others, 1966). The direction in which the boulder debris 


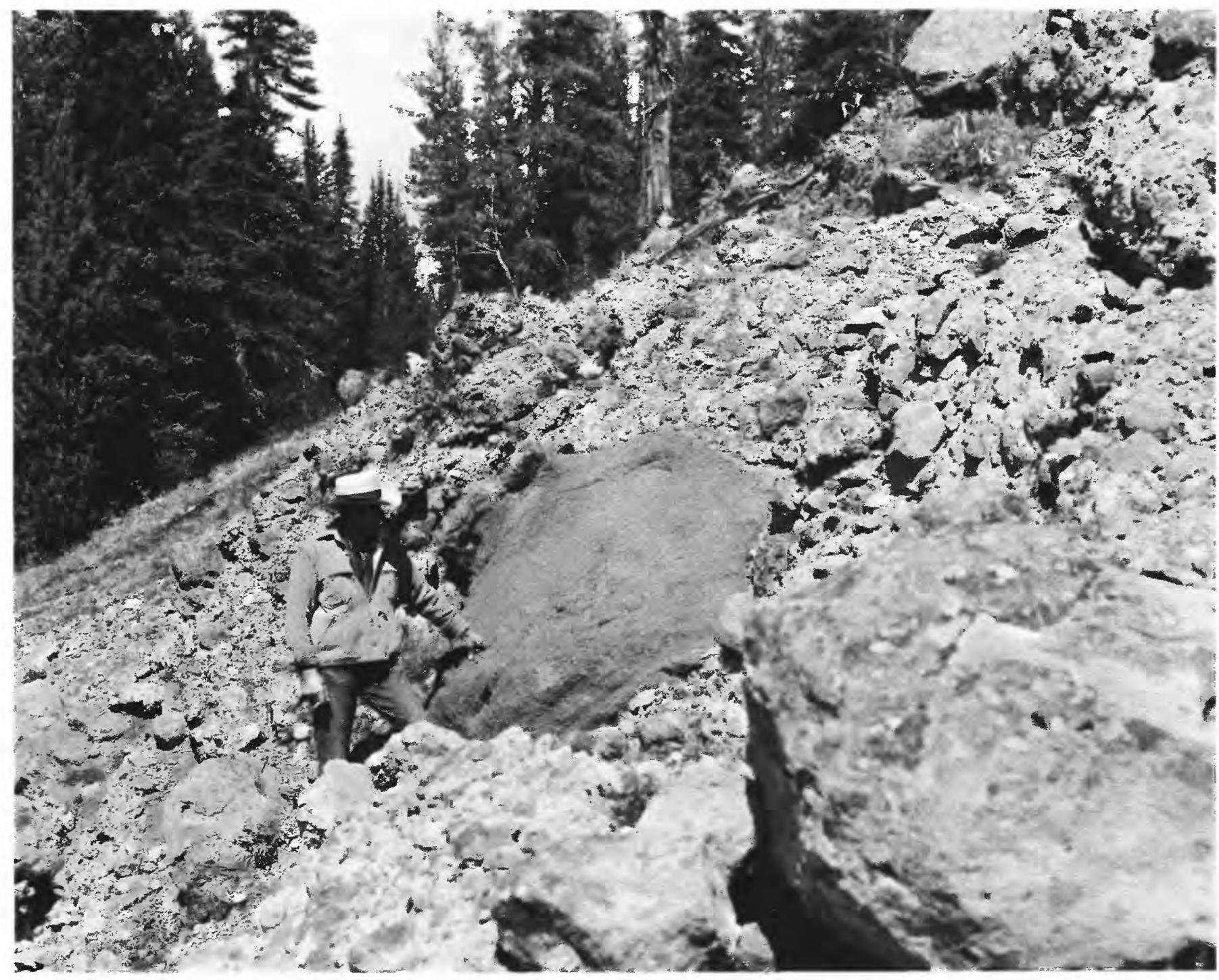

FIGURE 5.-Volcanic conglomerate in Wiggins Formation near section D, north margin of Emerald Lake vertebrate fossil locality. Huge boulder in center is of dark-green deeply weathered basalt; others are of red, gray, and black andesite and red, green, and black basalt in a coarse-grained gray crystal and lithic tuff matrix. Note lack of bedding and orientation. For areal relations see figures 3 , 11 , and 14 . Photograph by J. D. Love, Aug. 24, 1964.

moved can be inferred from regional studies by Smedes and Prostka (1972). The major vent areas during Wiggins time were probably in the Absaroka Range east and northeast of the Emerald Lake area.

The relations of the Wiggins Formation to the overlying White River Formation are discussed in some detail later. We now know that there is no intertonguing of the two formations; rather, instead, there is a time gap of at least $8 \mathrm{~m}$.y. (million years) during which 1,000 feet ( $305 \mathrm{~m}$ ) or more of the Wiggins Formation was eroded from the Emerald Lake locality, and a steep-sided channel was cut. The vertebrate-bearing White River Formation was subsequently deposited in this channel.

Wood and leaves are the only identifiable fossils found in the Wiggins Formation in the Emerald Lake area, but none is diagnostic. The Oligocene or Oligocene(?) age of the Wiggins Formation was first questioned by Rohrer and Obradovich (1969) on the basis of two hornblende samples, from near the base of the formation, that yielded Eocene potassium-argon ages of $46.2 \pm 1.8 \mathrm{~m} . \mathrm{y}$. and 46.52 .3 m.y. Subsequently, potassium-argon ages determined from samples taken on the southeast face of Castle Rock, 3 miles $(4.8 \mathrm{~km})$ south-southwest of the principal reference section of the Wiggins Formation (fig. 1, loc. 6; Smedes and Prostka, 1972, p. C31-C32; also, J. D. Obradovich, written commun., 1972) and in the adjacent areas show that the formation ranges in age from about 47 m.y. in the lower part to about $43 \mathrm{~m}$.y. near the top. 


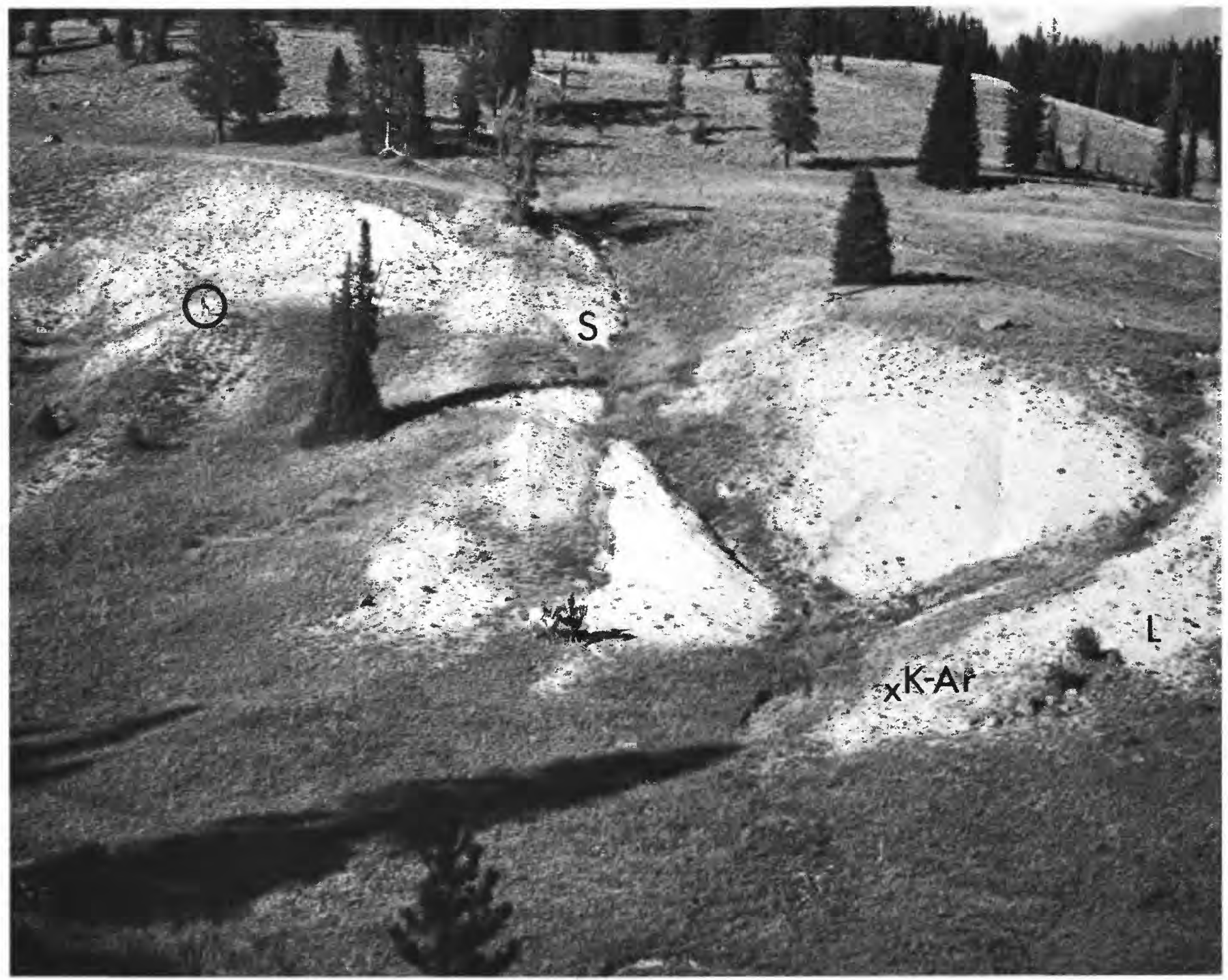

FIGURE 6.-View northeast at locality of measured section C of White River Formation. Man (in circle) and horses (lower center) show scale. $\mathrm{L}$ and $\mathrm{S}$, vertebrate fossil localities, figure 13 and table 3. K-Ar, locality of Obradovich potassium-argon sample 14 from which an

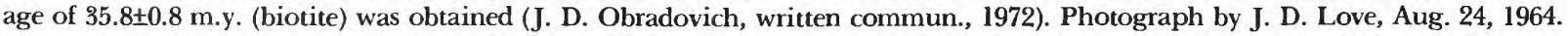

\section{WHITE RIVER FORMATION (OLIGOCENE)}

All the known outcrops of the White River Formation in the Emerald Lake area are shown in figure 3. The formation consists of about 100 feet $(30.5 \mathrm{~m})$ of white soft tuffaceous strata that were deposited in a steep-sided channel cut in the older volcanic conglomerates of the Wiggins Formation. Outcrops typically are sparsely vegetated and weather into rounded bare badlands (figs. 6-9) similar to those of the same age and containing the same species of vertebrate fossils in central and eastern Wyoming.

The rock is chiefly light-gray to tan tuffaceous claystone and siltstone that weathers white. The rocks are so massive that it is almost impossible to find bedding on which reliable dips can be obtained. Weathered surfaces commonly have a finely blocky or hackly appearance (fig. 9). Bentonitic layers have puffy outcrop surfaces. Several vitric tuffs are present, one of which has sufficient biotite for a potassium-argon age of $35.8 \pm 0.8 \mathrm{~m} . \mathrm{y}$. (measured section C, unit 1, p. 21; fig. 6; table 2) by J. D. Obradovich (written commun., 1972). Volcanic conglomerate lenses with lithology indistinguishable from that of volcanic conglomerate in the Wiggins Formation, and apparently derived from it, are most common in the basal and upper parts of the White River in the northern and southern exposures in the outcrop area.

The following series of stratigraphic sections (locations shown in fig. 3) of the Wiggins and White River Forma- 


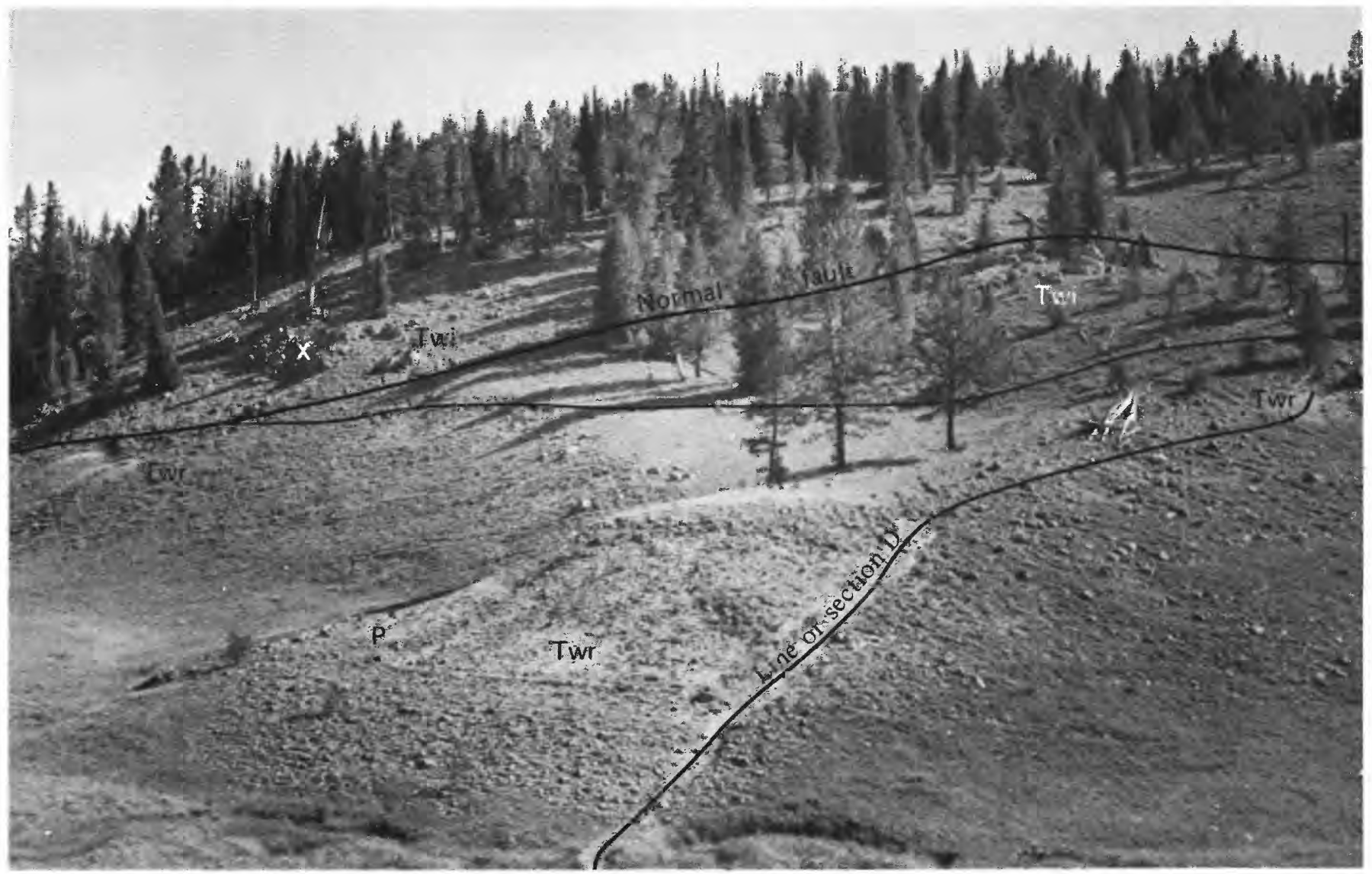

FIGURE 7.-View northeast at locality of measured section D. P, vertebrate fossil locality; Twr, White River Formation; Twi, volcanic conglomerate in Wiggins Formation. Normal fault is down on camera side. X, location of closeup view of conglomerate (fig. 5). Photograph by J. D. Love, Aug. 24, 1964.

tions were measured to show the relations of the two formations, the details of lithology, and the position of samples collected for various types of analyses, and to indicate horizons of vertebrate fossils.

SECTION A.-A completely exposed sequence of the Wiggins Formation on the steep northwest-facing slope at the north end (east side of the canyon) of a southeast-flowing tributary to Mink Creek

$$
\text { [Measured by J. D. Love, 1953. See fig. 3] }
$$

Thickness (feet) (metres)

Wiggins Formation (part):

3. Volcanic conglomerate, grayish-brown; a jumble of unoriented, unsized, and unsorted rock fragments; very coarse grained with subrounded pebbles to boulders of andesite and basalt embedded in pink to gray crystal and lithic, very hard, tightly cemented tuff matrix; figure 4 shows this unit

2. Sandstone, gray, coarse-grained, loosely cemented, tuffaceous, massive, hard; contains lenses of red, gray, and black andesite and basalt pebbles; grains are angular to subrounded, many are pink to black; some yellow fragments of silicified wood; one orange to lemon-yellow clayey parting; unit is a local lens with strike N. $60^{\circ} \mathrm{W}$., dip $10^{\circ} \mathrm{SW}$.
Wiggins Formation (part)-Continued

1. Volcanic conglomerate, grayish-brown; a jumble of unoriented, unsized, and unsorted rock fragments; subrounded boulders as much as 4 feet $(1.2 \mathrm{~m})$ in diameter, but average size is $1-2$ in. $(2.5-5 \mathrm{~cm})$; some boulders angular, others highly rounded; embedded in pink to gray coarse-grained crystal and lithic, very hard, tightly cemented tuff matrix; nearly massive, but has some bedding planes that show dip to southwest; roundstones are chiefly of coarse-grained pyroxene and hornblende andesite with euhedral phenocrysts in a red, gray, or black fine-grained matrix; thin sections Wyo. 719, 720, 721, 722, 723, and two unnumbered slides are basis for petrographic identifications; many seams of milky white coarsely crystalline calcite and clear coarsely crystalline quartz cut conglomerate; unit measured up from creek level in canyon .

Total thickness of measured part of Wiggins Formation.

Underlying rocks are not exposed, but regional relations suggest that 


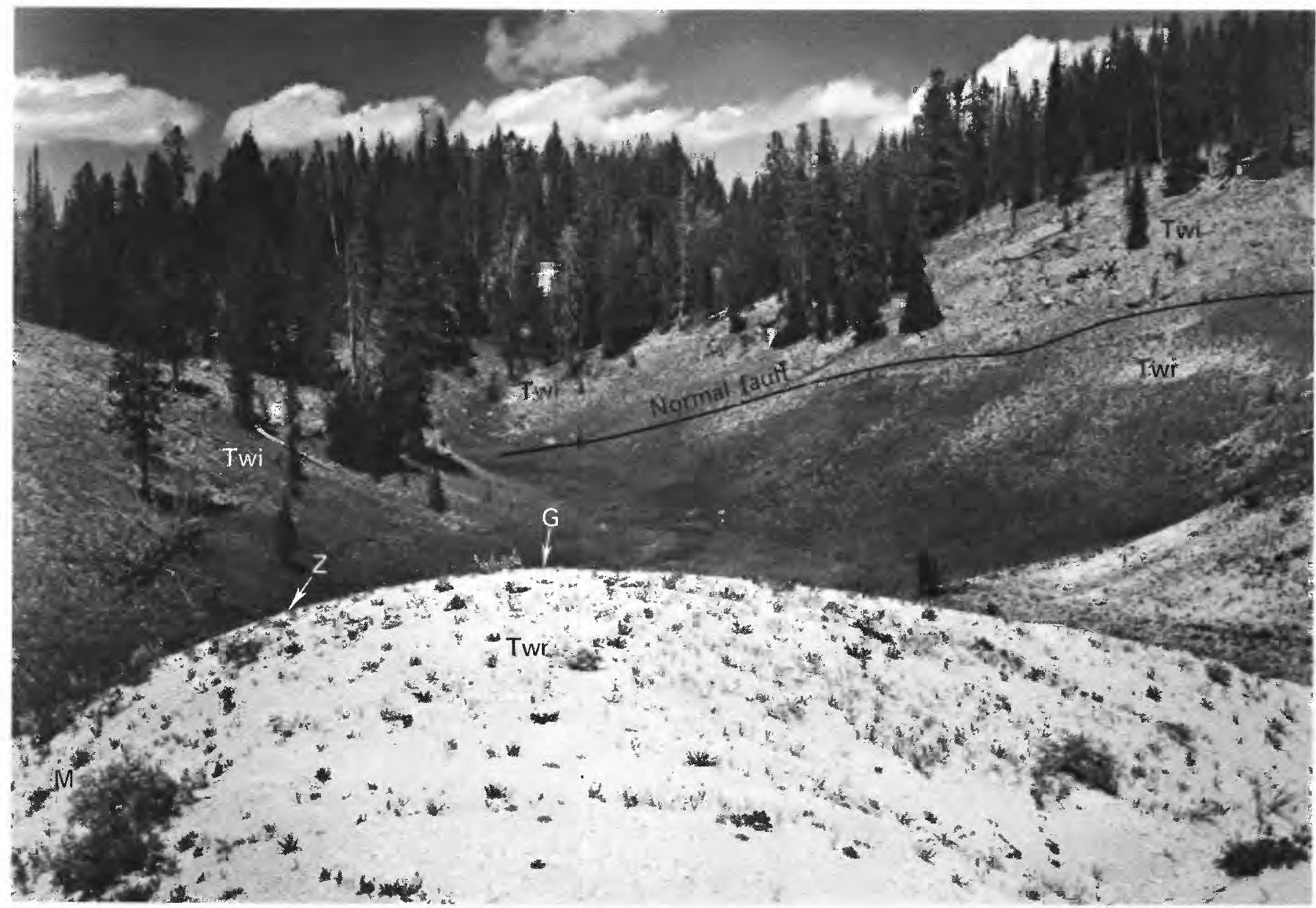

Figure 8.-View north from camera point on white knoll southwest of measured section D. G, M, P, and Z, vertebrate fossil localities. (For aerial view of these localities see fig. 13.) Twr, White River Formation; Twi, volcanic conglomerate in Wiggins Formation. Normal fault is down on camera side. Location of closeup view of conglomerate in Wiggins Formation (fig. 5) at arrow point to left of $X$. $\mathrm{E}$, site of measured section E of Wiggins Formation. Closeup of hackly tuffaceous claystone in foreground is shown in Figure 9. Photograph by J. D. Love, Aug. 24, 1964.

Wiggins Formation (part)-Continued

Paleozoic carbonate rocks (possibly the Madison Limestone) is probably about 100 feet $(30 \mathrm{~m})$ below the floor of the canyon, which has an altitude of 8,340 feet at section $A$. The estimated thickness is based on average dips and on a projection of pre-Wiggins topographic relief. The Wiggins-Paleozoic contact 3,500 feet $(1,070 \mathrm{~m})$ northeast is at 8,600 feet and at the mouth of the canyon, about the same distance southeast, it is $8,100-8,200$ feet (fig. 3 ).

SECTION B.-White River Formation exposed on the north side of a small southwestward-flowing ravine about one-fourth mile $(0.4 \mathrm{~km})$ north of section $A$

[Measured by J. D. Love, 1953. See fig. 3]

White River Formation (part):

4. Claystone and siltstone, pale-flesh pink; weathers white; jointed; massive; contains many birdshot-size (about $1.5 \mathrm{~mm}$ ) rounded claystone pellets; black manganese staining common; sparse small pupillidlike gastropods; thin section Wyo. 714 shows green amphibole crystals in a carbonate claystone
White River Formation (part)-Continued

matrix; uranium analysis LW-752 (lab. No. 152664) has 0.0004 percent uranium (Ivan Barlow, analyst, rept. TWC-5963, May 15, 1958); sample submitted to E. B. Leopold for pollen study was nonproductive.

3. Pellet tuff, light-tan; composed of rounded pellets $1 \mathrm{~mm}$ to $1 \mathrm{~cm}$ in diameter of brown and gray tuff and claystone and tiny crystals of plagioclase and pyroxene in a gray smoothfeeling matrix; many open spaces between pellets make rock porous, soft, and crumbly; uranium analysis LW-753 (lab. No. 152665) from middle has 0.0005 percent uranium (Ivan Barlow, analyst, rept. TWC-5963, May $15,1958)$.

2. Claystone and siltstone, light-tan; weathers white with some localized pale pink and green mottling; some small subangular pebbles of, greenish-gray and brown dense hard andesite(?); numerous rounded claystone pellets; many pink and black flecks like
Thickness (feet) (metres) 


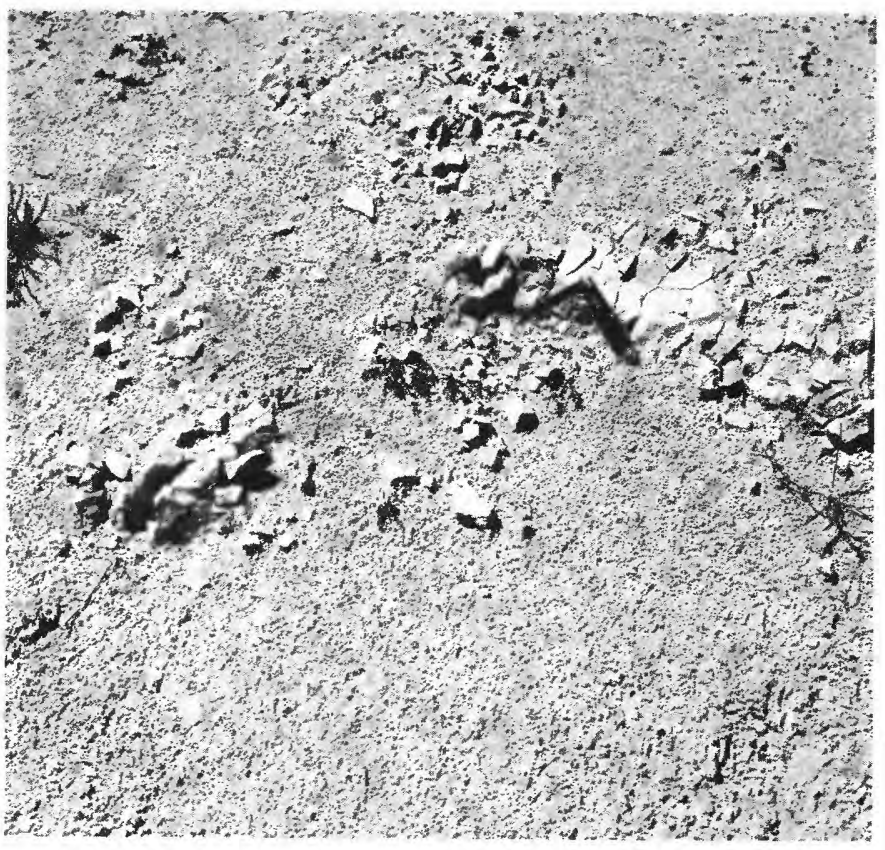

Figure 9.-Detail of lithology of white brittle hackly tuffaceous claystone in White River Formation, showing characteristic surficial conchoidal fracturing. Coarsely blocky areas have higher calcium carbonate content. Site is at locality $M$, figure 13 . Photograph by J. D. Love, Aug. 21, 1969.

White River Formation (part)-Continued those in tuffs in the White River Formation of central Wyoming; Rock analysis 148136 (LW-703, rept. IRC-140, Aug. 22, 1956, analysts P. L. D. Elmore, K. E. White, S. D. Botts) from base of unit showed rock to have 21 percent $\mathrm{CaO}$, which is much too high to make the $\mathrm{SiO}_{2}$. content meaningful in terms of actual composition of the volcanic fraction; separate sample submitted to E. B. Leopold for pollen study was nonproductive

Thickness (feet) (metres)

5

1. Tuff and conglomerate, interbedded; tuff is purplish gray to tan, with some yellow to green-tinged layers; coarse grained, porous limy, crumbly; some fine-grained beds similar to those of overlying unit; many red, purple, gray, and black angular granules and pebbles of andesite and basalt; rock speckled with abundant black manganese dendrites, in places so abundant that it has a gray appearance; many large and small bone fragments in tuff part; horizontal bedding present near top; conglomerate has angular to subrounded fragments of red, gray, and green andesite and black basalt as much as 5 in. $(13 \mathrm{~cm})$; thin section Wyo. 716 of tuff shows it to be a lithic crystal vitric tuff with plagioclase $\mathrm{An}_{54}$ (sodic labradorite), augite, green amphibole, and oxyhornblende. Rock fragments are of vitric tuff, pumice, brown obsidian, andesite(?), porphyritic augite and amphibole rock, and augite basalt. Glass

White River Formation (part)-Continued

Thickness (feet) (metres) shards are curved and highly altered. Thin section Wyo. 717 of a tuff in the basal 10 feet $(3 \mathrm{~m})$ shows it to be a coarse-grained mafic tuff of angular rock fragments in a carbonate matrix. Plagioclase is $\mathrm{An}_{68}$, and mineral fragments are orthopyroxene, clinopyroxene, quartz with undulatory extinction, brown-green and red-brown biotite, magnetite, oxyhornblende, olivine, and green amphibole. Rock fragments are of basalt, olivine basalt, porphyry, vitrophyre with augite phenocrysts, and quartzite. Uranium analysis LW-274 (lab. No. 99527) of a large mammal bone fragment has 0.005 percent equivalent uranium, 0.006 percent uranium, and 0.10 percent vanadium oxide $\left(V_{2} \mathrm{O}_{5}\right)(\mathrm{S}$. Furman, W. Mountjoy, P. Schuck, and J. Wilson, analysts, rept. TDC-3273, Nov. 17, 1953). Sample of light-gray blocky tuff submitted to E. B. Leopold for pollen study was nonproductive

Total thickness of measured part of White

River Formation.

$90 \quad 27$

Underlying rocks are not exposed. If dip of beds is horizontal, as is suggested in unit 1 , that unit is probably partly correlative with the lower strata containing vertebrate fossils to the west at loc. $T$ (fig. 13; table 3).

SECTION C. - White River Formation exposed on a southwestwardfacing white slope on the northeast side of a straight faultline valley about three-eighths of a mile $(600 \mathrm{~m})$ west of section B

[Measured by J. D. Love, 1964. See fig. 9]

White River Formation (part):

4. Tuff, claystone, siltstone, and conglomerate, white; angular red, brown, and gray andesite and black basalt fragments as much as $\mathbf{1}$ foot $(0.3 \mathrm{~m})$ in diameter (reworked from Wiggins Formation) in white to gray tuff and claystone matrix; unit laps against north side of channel cut in volcanic conglomerate of Wiggins Formation.

3. Claystone and siltstone, light-tan; weathers white; tuffaceous, blocky, very hard; secondarily silicified and calcified; abundant calcite, quartz-crystal, and chalcedony seams with various orientations, probably related to fault in valley to west; some of the chalcedony fluoresces yellow under ultraviolet light Rock analysis of a tuffaceous layer near top of unit is given in table 1 (lab. No. 162632). Uranium analysis LW-272 (lab. No. 99525) has 0.005 percent equivalent uranium (uranium not determined). Another sample of similar chalcedony, however, LW-754 (lab. No. 152666), has $<0.001$ percent equivalent uranium and 0.0018 percent uranium (Ivan Barlow, analyst, rept. TWC-5963, May 15, 1958).

2. Claystone and siltstone, light-tan; weathers white; blocky, very limy; sporadic red and black andesite and basalt pebbles; top of unit
Thickness (feet) (metres) 
White River Formation (part)-Continued

yielded skull of Ischyromys veterior at locality $S$ (figs. 6, 13; table 3)

1. Claystone and siltstone, light-tan; weathers white; blocky, massive; many quartz, chalcedony, and calcite seams, as in unit 3; fragmentary rhinoceros(?) tooth 6 feet $(1.8 \mathrm{~m})$ above base; jaw of Mesohippus cf. M. hypostylus 11 feet $(3.9 \mathrm{~m})$ above base at locality L (figs. 6, 13; table 3). J. D. Obradovich (written commun., 1972) obtained a potassium-argon age of 35.8 m.y. on his sample 14 from white biotite-rich tuff 2 feet $(0.6 \mathrm{~m})$ thick, 10 feet $(3 \mathrm{~m})$ above base of unit at locality $\mathrm{K}$-Ar (fig. 6)

\section{$\underline{45} \quad \underline{13.7}$ \\ $100 \quad 30.4$}

Approximate thickness of measured part of White River Formation

Underlying beds are below creek level and are not exposed.

SECTION D. White River Formation on a southwestward-facing slope about 1,000 feet $(300 \mathrm{~m}$ ) northwest of section $C$ (fig. 3), extending from creek level eastward up a washed-out horse trail which contains some of the freshest exposures

[Measured by J. D. Love, 1964]

White River Formation (part):

9. Tuff and conglomerate, white, limy, hard; clayey near top; red and black porphyritic andesite fragments, as much as 6 inches (15 $\mathrm{cm}$ ) long, reworked from Wiggins Formation along adjacent channel margin; numerous smooth-sided cylindrical objects as much as 1 inch $(2.5 \mathrm{~cm})$ long and three-eighths inch $(0.95 \mathrm{~cm})$ in diameter, possibly pupa cases of a carnivorous beetle of the type common in the White River Formation of central and eastern Wyoming (P. O. McGrew, oral commun., 1968). Thin section Wyo. 719 is a lithic crystal tuff in a carbonate matrix containing many highly altered rock fragments of porphyritic hornblende andesite, olivine basalt, and pyroxene basalt; matrix of thin section has plagioclase, orthopyroxene, pigeonitic augite, quartz, red-brown biotite, amphibole, magnetite, and pyrite...................

8. Claystone and siltstone, light-brown to tan, hard, blocky, massive, lightweight, noncalcareous; contains subrounded granules and small pebbles of red and black andesite, increasing in abundance from bottom to top...

7. Claystone, siltstone, and vitric tuff; claystone is pale brown; vitric tuff is light green and weathers white; both are soft and noncalcareous; glass shards are present in tuff but are somewhat altered. Rock analysis of tuff is given in table 1 (lab. No. 164307). Claystone and siltstone have sporadic small granules of andesite and black pyroxene crystals.

6. Claystone and siltstone, light-brown; weathers light gray; soft, slightly bentonitic, finely blocky at surface; light-gray nodular zone in top 1 foot $(0.3 \mathrm{~m})$; about 3 feet $(1 \mathrm{~m})$ above
White River Formation (part)-Continued

base and 75 feet $(23 \mathrm{~m})$ north is 1 foot $(0.3$ $\mathrm{m}$ ) of light-gray lightweight porous noncalcareous vitric tuff with somewhat altered glass shards. Rock analysis of this tuff is given in table 1 (lab. No. 164306).

5. Claystone and siltstone, light-brown; weathers light gray, hard, blocky; in top 1 foot is an irregular, slightly limy zone that weathers into hard blocks; numerous tiny thin glass shards

Thickness

(feet) (metres)

4. Pumicite conglomerate and pumicite, white to greenish-gray, lenticular; disappears 15 feet $(5 \mathrm{~m})$ north of line of section; covered to the south; subrounded to angular red and black andesite fragments as much as 4 inches $(10 \mathrm{~cm})$ long; mass of unoriented well-preserved glass shards in top 1 foot $(0.3 \mathrm{~m})$; noncalcareous, porous; breaks into lumpy nodular fragments, not at all like overlying blocky claystone; lower half is coarser grained and contains more pebbles and cobbles ........

3. Claystone and siltstone, light-tan; weathers light gray, hard, blocky; numerous red and black andesite granules and pebbles; abundant moderately well preserved shards; at approximate top of this unit and in same type of lithology 75 feet north of line of section, around bend in hill, is vertebrate fossil locality $\mathbf{P}$ (figs. 8, 13; table 3), which yielded jaws of Merycoidodon forsythae..

2. Claystone and siltstone, pinkish-brown; weathers light gray, hard, blocky; much denser and finer grained than overlying units; noncalcareous; sparse pebbles; many small glass shards; pupa case(?) 3 feet above base..

$0-4 \quad 0-1.2$

1. Claystone; brown and plastic near base, pale pink and green and hard and blocky in middle and upper parts; grades into overlying unit; base is at water level in creek.

Approximate thickness of measured part of White River Formation

Underlying beds are not exposed.

Section E.-Wiggins Formation

[Measured, by J. D. Love, 1964, on east-facing slope about $500 \mathrm{ft}(150 \mathrm{~m})$ northwest of base of measured section $D$, extending from creek level westward to top of hill. See figs. 3, 8]

Thicknes. (feet) (metres)

113.35 Wiggins Formation:

1. Volcanic conglomerate. Contains a few thin light-gray beds of very coarse grained crystal and lithic tuff, but conglomerate matrix predominates over boulders. Section is cut by a small intrusive mass of red and black pyroxene basalt, the margins of which show red alteration.

Total thickness of measured part of Wiggins Formation

Chemical analyses of the beds richest in vitric tuff are given in table 1; comparative data for Oligocene rocks in adjacent parts of Wyoming are also given. Common 
oxide contents of the tuffs in the White River Formation of central Wyoming and at the Emerald Lake locality are remarkably similar, the only differences being a slightly higher iron and titanium content at Emerald Lake and a slightly higher $\mathrm{K}_{2} \mathrm{O}$ content in central $\mathrm{W}$ yoming. The number of analyses is so few, however, that these differences may not be statistically meaningful.

Figure 10 presents a comparison of semiquantitative spectrographic analyses of tuffs in the White River Formation at the Emerald Lake locality with those from similarappearing white tuffs in the White River Formation of central Wyoming, which likewise contain vertebrate fossils of early Oligocene (Chadronian) age. Comparison is also made with white tuffs in the basal part of the Wiggins Formation on and south of Carter Mountain (fig. 1, loc. 7), 55 miles ( $88 \mathrm{~km}$ ) east-northeast of Emerald Lake (Nelson and Pierce, 1968, fig. 1). The geologic setting and stratigraphic position of the White River samples in central Wyoming have been described elsewhere (Love, 1970, p. C62-C65 and fig. 35). The Wiggins Formation on Carter Mountain has recently been determined to be Eocene in age on the basis of a potassium-argon age of 46.7 m.y. (J. D. Obradovich, written commun., 1972; table 2). This age was determined from a white tuff overlying paleyellow bentonitic tuffs that contain a late Eocene vertebrate fauna (E. L. Simons, written commun., 1963). An Oligocene age of $33.9 \mathrm{~m}$.y. for the white tuff was reported by Houston (1964) but is believed by Obradovich to be in error because the date was based on partly altered biotite.

The spectrographic analyses are also compared (fig. 10) with the elemental composition of the Earth's crust. Data on crustal abundance are from Mason (1958, p. 44).

Because tuffaceous Oligocene rocks in Wyoming and elsewhere have been considered to be possible sources for some uranium occurrences in the region (Love, 1952, 1954a; Denson and Gill, 1956; Harshman, 1972), tuff, bone, and water samples from the White River Formation were analyzed for uranium. Tuff and bone analyses are given in the description of the measured sections. Water from a spring (fig. 3) that flows an estimated 2,000 gallons (7,570 litres) of clear cold water per day from white blocky siltstone in the middle of the formation contains less than 2 parts per billion uranium (Wayne Mountjoy, analyst, Oct. 15, 1953). None of the rock samples shows an abnormally high amount of uranium. The yellow fluorescence of some secondary chalcedony, however, and the amount of uranium in the fossil bones, though small, indicate that some uranium was probably originally present in the tuff and was later redistributed and concentrated.

The stratigraphic relations between the White River and Wiggins Formations are obscured almost everywhere by thin deposits of glacial debris or landslide slumps, or are obscured by faulting. For this reason, in most places the evidence for the White River Formation being a channel-fill deposit, rather than intertonguing with the Wiggins Formation, is not convincing. However, one site was found on the steep hillside southeast of measured section B where nonconglomeratic soft tuffaceous claystones of the White River had been deposited on a $20^{\circ}$ slope cut into conglomerate in the Wiggins. New landslides and active erosion have partially stripped the slope, and so the relations can be clearly seen. Our interpretation of the areal relations of the White River Formation to the Wiggins is shown in figures 11 and 12.

The early Oligocene (Chadronian) age of the White River Formation in the Emerald Lake area is based in part on a potassium-argon age from unit 1 of measured section $\mathrm{C}$, and in part on vertebrate fossils. The potassium-argon sample is from a white biotite-rich tuff 2 feet $(0.6 \mathrm{~m})$ thick; it yielded an age of $35.8 \pm 0.8 \mathrm{~m} . \mathrm{y}$. (J. D. Obradovich, written commun., 1972; fig. 6, loc. K-Ar; table 2). This age is compatible with the early Oligocene (Chadronian) age as determined by the vertebrate fossils.

The disappearance of the 1948 and most of the 1953 vertebrate fossil collections, fossils from the White River Formation at the Emerald Lake locality, has been mentioned. The original records of identification of these fossil collections are in two memoranda from the late $\mathrm{M}$. J. Hough. The 1948 collections were identified (Hough, written commun., Jan. 5, 1950; listed in Love, 1952, p. 19) as follows: Poebrotherium sp., Teleodus uintensis, Ischyromys aff. I. pliacus, and Cylindrodon aff. C. fontis.

These came chiefly from sites $P, G, K, C, L, S, T$, and E, with $E$ being the most productive (figs. 13, 14). These identifications established the age of the enclosing strata to be Oligocene, although identifications of Teleodus uintensis (Duchesnean elsewhere) and Ischyromys aff. I. pliacus (=I. typus, Orellan elsewhere) were anomalous, if correct.

The 1953 collections from the same sites were identified (Hough, written commun., Dec. 18, 1953; listed in Love, 1954b) as follows: Cylindrodon cf. C. fontis, Ischyromys cf. I. parvidens (=I. veterior; Black, 1968a, p. 278), Megalagus brachyodon, Palaeolagus temnodon, Eutypomys sp., ?Teleodus cf. T. uintensis, and Poebrotherium sp.

The 1964, 1969, and 1971 collections, made by the Department of Vertebrate Paleontology of the American Museum of Natural History, contain the assemblage listed in table 3; a preliminary review of it was presented by McKenna (1972, p. 94-96).

We believe that specimens referred to as "Ischyromys, probably I. pliacus" by Mrs. Hough were most probably members of the same species (Ischyromys veterior) collected in 1964. Ischyromys cf. parvidens listed from the 1953 collections is accepted here as a synonym of $I$. veterior, following Black (1968a). The anomalous occurrence of Teleodus uintensis (Duchesnean elsewhere) reported by Mrs. Hough in 1950 likewise warrants further 
TABLE 1.-Rock analyses of tuffaceous strata of early Oligocene and Miocene age in the Emerald Lake,

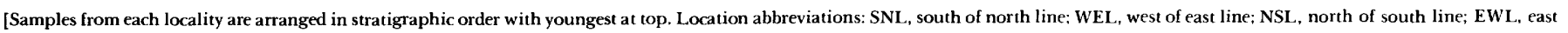

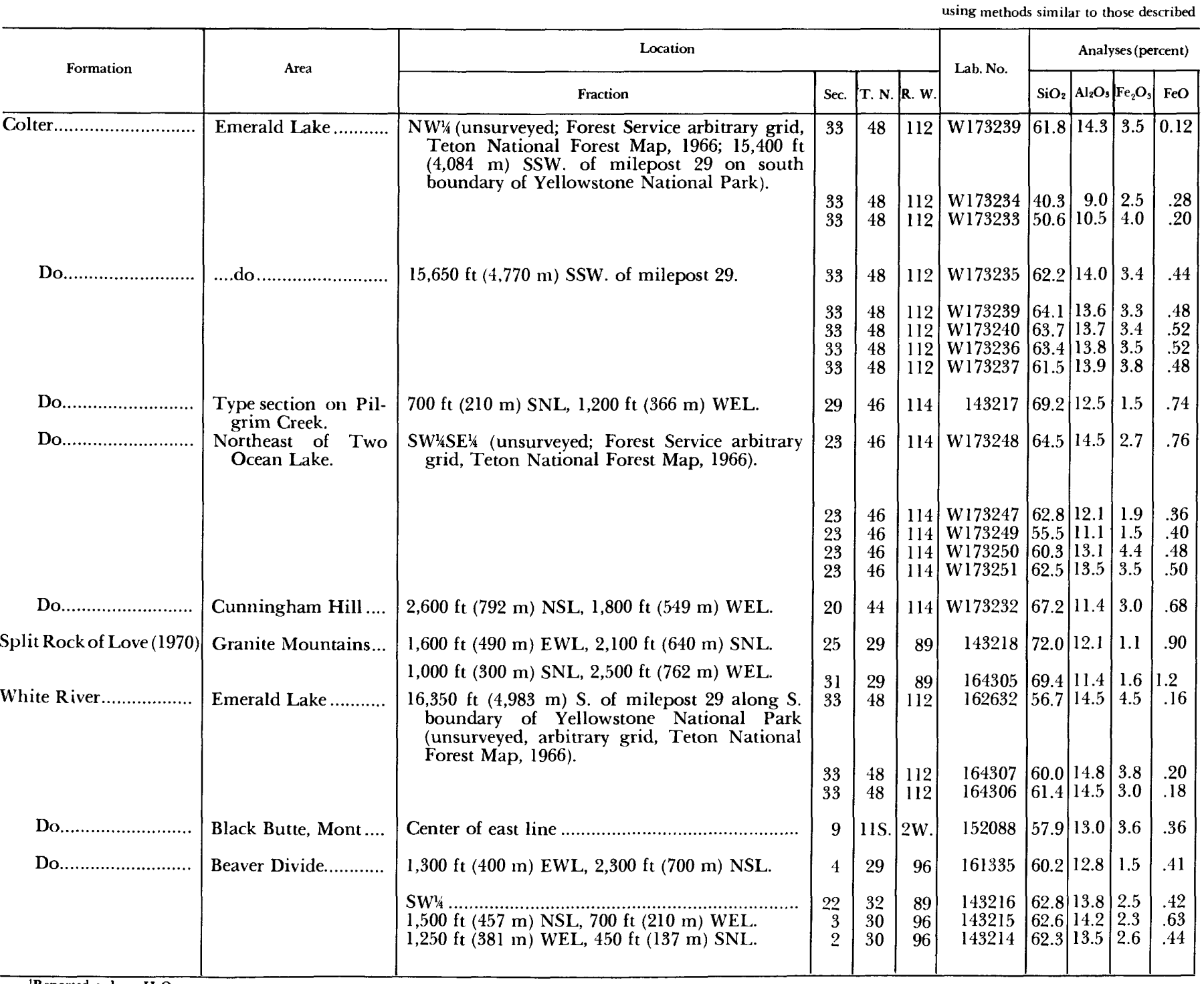

comment. Inasmuch as no additional specimens were found in any of the later collections, and because of the conflicting age assignments, it seems probable that her identification of this now-missing specimen was in error.

The early Oligocene (Chadronian) age of the Emerald Lake assemblage from the White River Formation is confirmed by the presence in the new collection of Palaeolagus temnodon, Paradjidaumo minor, Mesohippus cf. $M$. hypostylus, Merycoidodon forsythae, and Cylindrodon fontis. A similarity to the Main Pocket assemblage at Pipestone Springs, Mont., is apparent, although the Emerald Lake assemblage either is impoverished or, more probably, has been sampled incompletely. The position within the Chadronian land-mammal age of various reported assemblages is probably late Chadronian, rather than early as Mrs. Hough believed. (See Clark and Beerbower, in Clark and others, 1967.)
Most of the fossils obtained from the Emerald Lake assemblage were collected on the surface of the exposure labeled " $E$ " in figure 13. This site, which had already been sampled in 1948 and in 1953, was examined repeatedly after periods of light rain and snow during the 1964 visit. Surface concentrations of small mammal remains were constantly renewed, partly because of surficial disturbance caused by previous prospecting and partly because of the effects of moisture on the exposure. The site yielded additional material in 1969 and in 1971. This exposure should continue to produce fossils sparingly for some time to come.

No new taxa of vertebrate fossils restricted to the White River Formation at the Emerald Lake locality were recognized, and no biological or geochemical evidence was found that would indicate an environment significantly different from that of many other stream-side Chadronian 


\begin{tabular}{|c|c|c|c|c|c|c|c|c|c|c|}
\hline \multicolumn{10}{|c|}{ Analyses (percent)-Continued } & \multirow{2}{*}{ Remarks } \\
\hline $\mathrm{MgO}$ & $\mathrm{CaO}$ & $\mathrm{Na}_{2} \mathrm{O}$ & $\mathrm{K}_{2} \mathrm{O}$ & $\mathrm{TiO}_{2}$ & $\mathrm{P}_{2} \mathrm{O}_{5}$ & $\mathrm{MnO}$ & $\mathrm{H}_{2} \mathrm{O}-$ & $\mathrm{H}_{2} \mathrm{O}+$ & $\mathrm{CO}_{2}$ & \\
\hline 2.6 & 3.2 & 1.7 & 1.7 & 0.55 & 0.23 & 0.08 & 6.2 & 3.2 & $<0.05$ & $\begin{array}{l}\text { Pumice granule bed. This and following seven samples from approximately the same } \\
\text { locality are arranged in stratigraphic order. See fig. } 17 \text { for appearance of outcrop of } \\
\text { this and next two samples. }\end{array}$ \\
\hline 1.0 & 22.3 & 1.1 & 2.0 & .34 & .11 & .06 & 2.2 & 2.0 & $: 26.6$ & Clay pellet bed, sampled for pollen. \\
\hline 1.5 & 13.2 & 1.3 & 2.3 & .45 & .09 & .05 & 3.5 & 3.2 & 8.4 & Sandstone, olive-drab; weathers white; fine grained, soft. \\
\hline 2.4 & 3.4 & 1.7 & 2.6 & .56 & .08 & .04 & 4.8 & 4.0 & .08 & $\begin{array}{l}\text { Sandstone at top of exposure shown in fig. } 16 \text { and several hundred feet stratigraphically } \\
\text { below sample W173233. }\end{array}$ \\
\hline 2.1 & 3.0 & 1.5 & 2.9 & .53 & .11 & .08 & 4.2 & 4.0 & $<.05$ & Sandstone at horizon of aplodontid rodent jaw (figs. 16, 18). \\
\hline 2.1 & 3.5 & 2.1 & 2.7 & .57 & .16 & .05 & 3.8 & 3.3 & .05 & Sandstone $50 \mathrm{ft}(15 \mathrm{~m})$ below W173239. \\
\hline 1.8 & 3.6 & 1.9 & 3.0 & .56 & .12 & .08 & 3.4 & 3.7 & .08 & Sandstone $20 \mathrm{ft}(6 \mathrm{~m})$ above base of exposure shown in fig. 16 . \\
\hline 2.5 & 3.9 & 1.8 & 2.5 & .58 & .13 & .09 & 4.5 & 4.1 & .25 & Sandstone at base of exposure shown in fig. 16. \\
\hline .70 & 1.1 & 1.2 & 6.0 & .24 & .13 & .02 & \multicolumn{2}{|c|}{17.7} & $<.05$ & Pumicite in upper middle of $7,000-\mathrm{ft}(2,133-\mathrm{m})$-thick type section. \\
\hline 1.7 & 2.5 & 2.1 & 4.0 & .53 & .09 & .10 & \multicolumn{2}{|c|}{$2.2|4.1|$} & $<.05$ & $\begin{array}{l}\text { White soft massive to well-bedded tuff. This and following four samples are from basal } \\
\text { part of Colter Formation. This sample is from topmost bed of big white escarpment } \\
\text { exposing about } 500 \mathrm{ft}(150 \mathrm{~m}) \text { of beds. }\end{array}$ \\
\hline 1.4 & 4.5 & 1.5 & 4.6 & .21 & .07 & .09 & 2.9 & 4.7 & 2.2 & White vitric tuff, $70 \mathrm{ft}(21 \mathrm{~m})$ below top of exposure. \\
\hline 1.4 & 10.5 & 1.3 & 3.8 & .18 & .04 & .08 & 2.8 & 4.0 & 6.8 & Chalky white tuff, $100 \mathrm{ft}(30 \mathrm{~m})$ below W173247. \\
\hline 3.0 & 4.2 & 1.3 & 2.3 & .63 & .17 & .05 & 5.2 & 3.7 & .84 & Massive white lithic tuff, $20 \mathrm{ft}(6 \mathrm{~m})$ below W 173249 . \\
\hline 2.4 & 2.5 & 1.5 & 2.9 & .53 & .14 & .10 & 4.7 & 4.4 & $<.05$ & Blocky white siltstone near base of exposure. \\
\hline 1.3 & 1.5 & 1.1 & 3.9 & .45 & .03 & .04 & 3.9 & 4.7 & .05 & $\begin{array}{l}\text { White light-weight tuff with iridescent bubble cavities, about } 15 \mathrm{ft}(5 \mathrm{~m}) \text { above Cunning- } \\
\text { ham Hill vertebrate fossil bed. }\end{array}$ \\
\hline .19 & .81 & 2.1 & 6.0 & .22 & .14 & .02 & \multicolumn{2}{|c|}{14.9} & $<.05$ & Pumicite $10 \mathrm{ft}(3 \mathrm{~m})$ thick in upper part of type locality of the Split Rock Formation \\
\hline 1.4 & .75 & 2.0 & 5.4 & .27 & .10 & .10 & 1.2 & 4.9 & .08 & Pumicite (Love, 1970, table 7). \\
\hline 3.3 & 3.1 & 1.0 & 1.6 & .65 & .34 & .10 & 7.7 & 6.7 & $<.05$ & Tuff near top of unit 3 , section $C$. \\
\hline 3.2 & 2.5 & 1.1 & 2.2 & .68 & .20 & .07 & 6.5 & 4.3 & .16 & Pumicite, unit 7 , section $D$. \\
\hline 3.0 & 2.9 & 1.3 & 2.6 & .62 & .30 & .11 & 5.4 & 4.5 & .09 & Pumicite, unit 6 , section $D$. \\
\hline 1.6 & 7.0 & 1.4 & 2.4 & .64 & .19 & .14 & \multicolumn{2}{|c|}{17.8} & 3.9 & White tuff about $100 \mathrm{ft}(30 \mathrm{~m})$ above base of tuffaceous claystone containing early Oligocene \\
\hline .54 & 8.2 & 2.4 & 4.5 & .24 & .10 & .08 & .84 & 3.0 & 4.6 & $\begin{array}{l}\text { Pumicite, split of which has K-Ar age of } 32.2 \mathrm{~m} . \mathrm{y} . \text {, about } 300 \mathrm{ft}(90 \mathrm{~m}) \text { above base of } \\
\text { formation. }\end{array}$ \\
\hline 1.9 & 2.4 & 1.5 & 3.2 & .36 & .22 & .06 & 110. & & .28 & Pumicite. \\
\hline 1.8 & 2.2 & 1.5 & 3.5 & .37 & .23 & .04 & 110. & & .12 & Pumicite in upper part of formation; Van Houten (1964); measured section 2. \\
\hline 1.6 & 3.8 & 1.7 & 3.4 & .38 & .22 & .06 & 18 & & 1.4 & $\begin{array}{l}\text { Pumicite } 50 \mathrm{ft}(15 \mathrm{~m}) \text { above Beaver Divide Conglomerate Member and } 90 \mathrm{ft}(27 \mathrm{~m}) \text { above } \\
\text { base of formation; Van Houten (1964); measured section } 6 .\end{array}$ \\
\hline
\end{tabular}

assemblages. As now known, the fauna itself does not suggest deposition at an elevation significantly greater than the elevations of other representative Oligocene faunas, though geologic considerations (Love, 1952, 1956b; fig. 2) lead to the conclusion that the elevation at which Chadronian deposits were laid down increased steadily westward across Wyoming toward the Absaroka Range and Yellowstone National Park.

Sutton's locality of the White River Formation on East Fork Pilgrim Creek (fig. 1, loc. 3; Sutton and Black, 1972) had not been identified as Oligocene prior to his discovery of diagnostic mammals. The rocks are readily distinguishable from the adjacent type section of the Colter Formation in that they are very fine grained, bentonitic, and light greenish gray to yellowish gray to white, whereas the Colter is coarse-grained tuff, sandstone, and mafic volcanic conglomerate, nonbentonitic, and generally darker green, brown, and gray. Some white tuffs occur in the Colter, but they are much harder and coarser grained than those in the White River Formation.

Most outcrops of the White River Formation on East Fork Pilgrim Creek are contorted and displaced by landslides that were facilitated by the bentonitic nature of the strata. Only one outcrop is nearly in place. It is shown on the geologic map of the Two Ocean Lake quadrangle (Love, 1973) and consists of about 30 feet $(9 \mathrm{~m})$ of claystone and tuff. It yielded the following lower Oligocene (Chadronian) vertebrate fossils (Sutton and Black, 1972, p. 77-78):

\section{Parectypodus? \\ Domnina \\ Palaeolagus \\ Cylindrodon \\ Palaeogale}




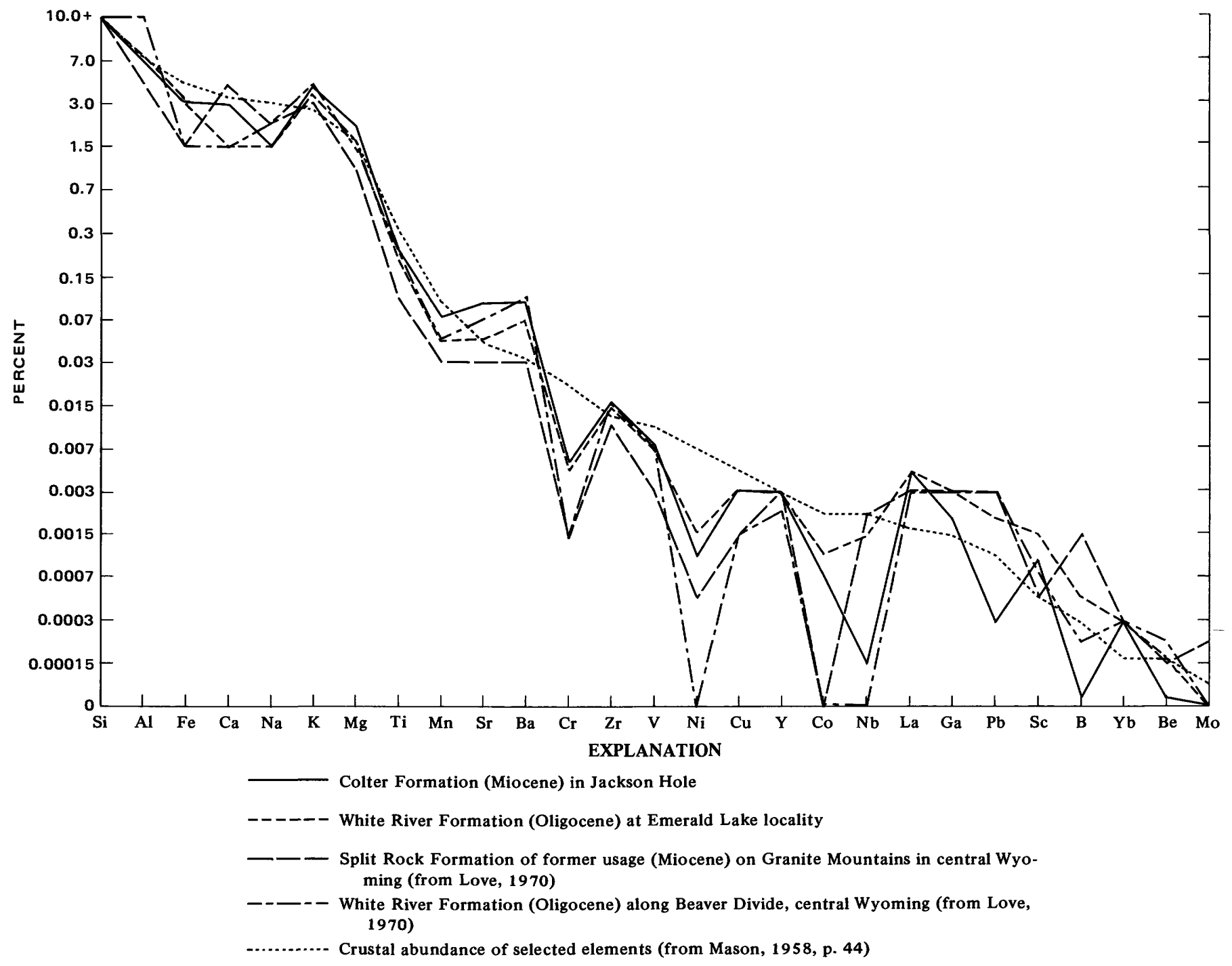

FigURE 10.-Semiquantitative spectrographic analyses of Colter Formation (six samples) at the Emerald Lake locality and elsewhere in Jackson Hole, and White River Formation (seven samples) at Emerald Lake locality, plotted to show similarities and differences in abundance of selected elements with those previously published for Miocene and Oligocene rocks in central Wyoming (Love, 1970).

titanothere

hyracodont?

tapir?

artiodactyl indet.

lizard

The new regionwide data that indicate the Wiggins Formation to be Eocene in age rather than Oligocene are of far-reaching significance in terms of geologic history and the source of volcanic sediments. For many years most workers thought that the Wiggins was a lateral coarse clastic equivalent of the White River Formation of central and eastern Wyoming and that the volcanic debris came largely from vents in the Yellowstone-Absaroka volcanic area. It now is clear that this interpretation is in error. In
Elements are arranged, from left to right, in order of decreasing abundance in the Earth's crust (Mason, 1958, p. 44). Values are reported in percent to the nearest number in the series $7,3,1.5,0.7$, and so forth; at least 60 percent of results are expected to be in the correct range.

the White River Formation of the Emerald Lake and Pilgrim Creek areas, no coarse clastic volcanic debris was found that could not have been reworked from older sources.

The closest well-documented Oligocene rocks northwest of Emerald Lake are 100 miles $(160 \mathrm{~km})$ away, high on the west side of the Gravelly Range in Montana (fig. 1, loc. 2). This is on the northwest side of the Yellowstone-Absaroka volcanic area. The rocks consist of white blocky claystone, siltstone, and tuff that are reported to intertongue with volcanic conglomerate of andesitic composition (Mann, 1954, p. 43). This relationship has not been reexamined to determine whether the intertonguing is actually reworking of the older debris. The 
TABLE 2.-Potassium-argon ages on some Oligocene and Eocene rocks in northwestern and central Wyomıng

Locality Age (m.y.)

Formation and age

Locality data and reference

Emerald Lake $35.8 \pm 0.8$ White River (Oligocene)

Beaver Divide (Ellis Ranch).

$32.2 \pm 2.0 \quad \ldots$. do..

East Beaver Divide (Lone Tree Gulch).

Badwater. $34.4 \pm 1.4$

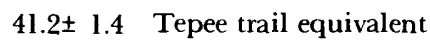
(late Eocene).

Wiggins Peak $43.1 \pm 1.1$ Wiggins (Eocene)

Castle Rock $44.6 \pm 1.2$

$46.7 \pm 1.5$ ....do...

$47.1 \pm 1.3$ .do.......

Duncan Ranch Aycross (middle Eocene)

\section{Sam} Sample 71-0-14, white biotite tuff in measured section $C$, unit 1 , associated with fossil mammals of early Oligocene (Chadronian) age. 16,000 ft $(4,900 \mathrm{~m})$ due south of milepost 29 along south boundary. of Yellowstone National Park. Sample collected and analyzed by J. D. Obradovich (written commun., June 19, 1972).

White biotitic tuff about $300 \mathrm{ft}(90 \mathrm{~m})$ above base of formation, $1,300 \mathrm{ft}$ $(400 \mathrm{~m})$ east of west line, $2,300 \mathrm{ft}(700 \mathrm{~m})$ north of south line of sec. 4, T. 29 N., R. 96 W. Sample collected by J. D. Love, analyzed by Geochron Laboratory (Love, 1970, table 5).

Six samples representing four beds of white tuff within a stratigraphic interval of about $500 \mathrm{ft}(150 \mathrm{~m})$; section contains fossil mammals of early Oligocene (Chadronian) age (Emry, 1973). SE药 sec. 23 to $\mathrm{E}^{1 / 2} \mathrm{sec}$. 22, T. 31 N., R. 83 W. (corrected location). Samples collected and analyzed by Evernden, Savage, Curtis, and James (1964, samples KA895, 897-900, and 1032, p. 185, 190).

Glass from white vitric tuff below vertebrate fossils of late Oligocene age. Sec. 24, T. 39 N., R. 89 W. Sample collected and reported by Black (1969).

Greenish-white biotite tuff associated with vertebrate fossils of late Eocene age. Sec. 34, T. 39 N., R. 88 W. (corrected location). Sample collected and reported by Black (1969).

Sample 71-0-12, highest stratigraphic horizon of tuff suitable for age dating in Wiggins Formation on ridge northwest of Wiggins Peak. About sec. 35, T. 45 N., R. 105 W., unsurveyed (projected grid). Sample collected and analyzed by J. D. Obradovich (written commun., June 19, 1972).

Sample 70-0-15, vitrophyre within andesite flows forming cliff in upper part of Castle Rock. Horizon is probably $500-1,000 \mathrm{ft}(150-300 \mathrm{~m})$ stratigraphically below the Wiggins Peak sample. $\mathrm{NE}^{1 / 4} \mathrm{sec}$. 1, T. $43 \mathrm{~N}$., R. $105 \mathrm{~W}$., about 3 miles $(5 \mathrm{~km})$ southwest of principal reference section of Wiggins Formation. Sample collected and analyzed by J. D. Obradovich (quoted by Smedes and Prostka, 1972, p. C32).

Sample 70-0-18, fine-grained white pumice tuff about $300 \mathrm{ft}(90 \mathrm{~m})$ below sample 70-0-15 at same locality, same collector, same published reference. Sample 70-0-17, white coarse-grained pumice tuff marker bed $20 \mathrm{ft}(6 \mathrm{~m})$ below sample 70-0-18 at same locality, same collector, same reference.

Sample L72-132, gray biotite tuff, unit 20 in type section of Aycross Formation, directly overlying bed containing vertebrate fossils of middle Eocene age (Love, 1939). SW $1 / 4 \mathrm{NW}^{1 / 4} \mathrm{sec}$. 8, T. 7 N., R. 5 W. Sample analyzed by J. D. Obradovich (written commun., 1974). finer grained strata are lithologically very similar to strata of the White River Formation in the Emerald Lake area, and several collections of vertebrate fossils likewise indicate an early Oligocene age. Samples for chemical and uranium analyses and thin section study were collected by Love to compare with the Emerald Lake White River Formation. A rock analysis of the white tuff shows it to have a common oxide content almost identical to that of the White River Formation in the Emerald Lake area (table 1; lab. No. 152088, analysts P. L. D. EImore, S. D. Botts, M. D. Mack, Oct. 23, 1957).

The closest known Oligocene rocks east of Emerald Lake are on the crest of the Bighorn Mountains (McKenna and Love, 1972), 180 miles ( $310 \mathrm{~km}$ ) away, and at Badwater Creek, 180 miles $(310 \mathrm{~km})$ to the southeast at the south end of the Bighorn Mountains (Black, 1969). There is no way of determining whether these now-isolated remnants were parts of a continuous deposit in Oligocene time. The strata on the Bighorn Mountains are light-colored finegrained tuffaceous claystones and siltstones similar to those in northwestern Wyoming and likewise contain a sparse Chadronian fauna. The strata at Badwater Creek are tan siltstones and sandstones with a potassium-argon age of $34.4 \pm 1.4$ m.y. (early Oligocene-Chadronian) in the lower part and vertebrate fossils of late Oligocene aspect in the upper part (Black, 1969).

The White River Formation of central Wyoming has been studied in some detail (Van Houten, 1964; Love, 1970; Emry, 1973; Harshman, 1972). Most of the strata are siltstones and fine-grained sandstones except near local source areas with high relief; in these areas, coarse clastics are common. 

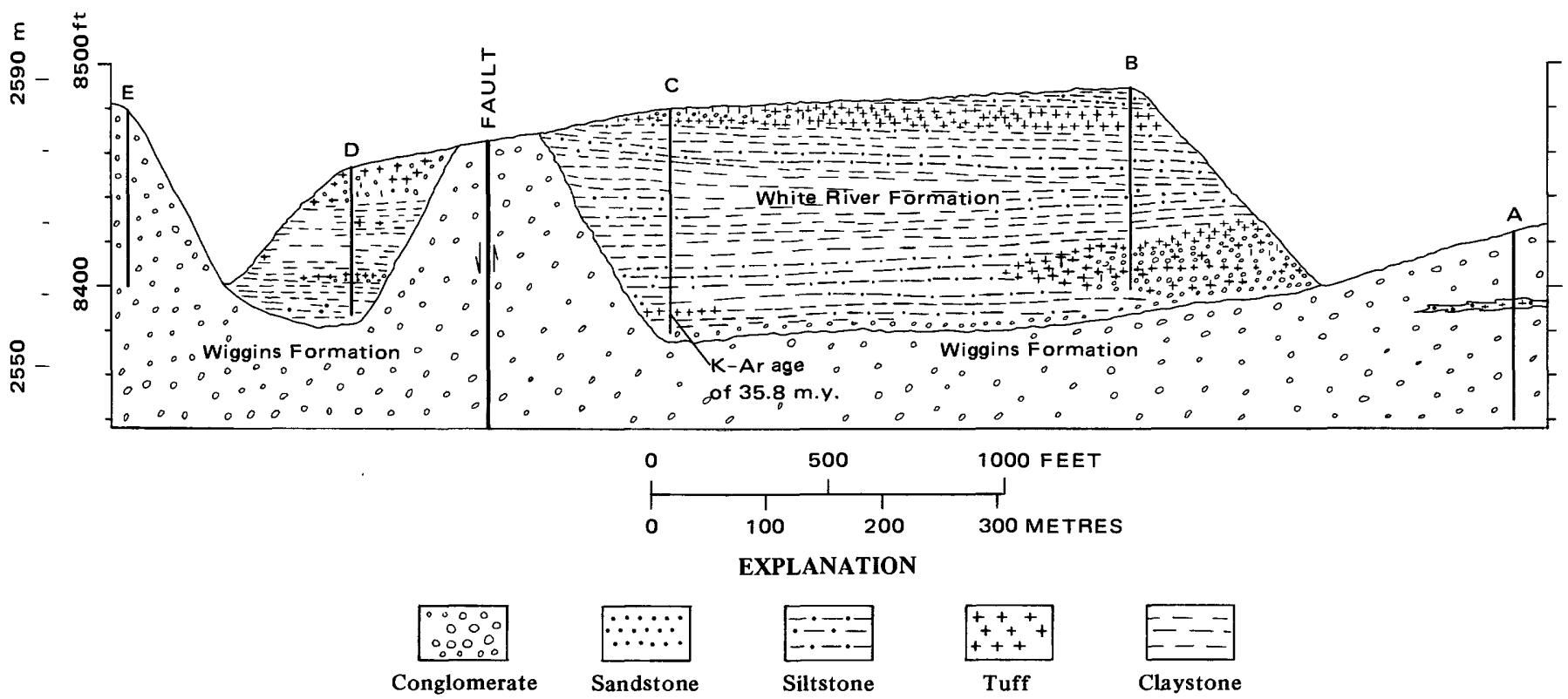

500

00

1000 FEET

100200

300

EXPLANATION
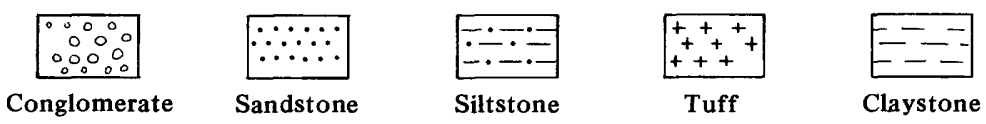

FIGURE 11.-Generalized interpretation of relations between volcanic conglomerate of Wiggins Formation and channel-fill deposit of White River Formation between measured sections $\mathrm{A}$ and $\mathrm{E}$.

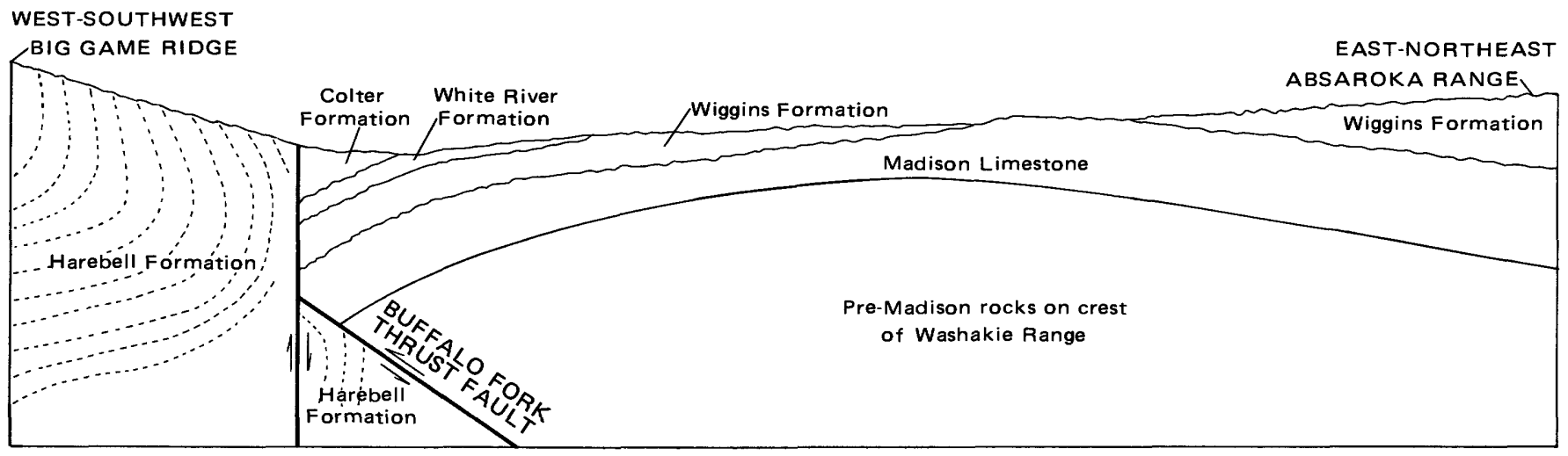

FiguRE 12.-Relations of Tertiary and older rocks in Emerald Lake area. Length of diagram 3.2 miles; no vertical exaggeration. About 0.75 mile $(1.2 \mathrm{~km})$ south of section A, pyroxene andesite and basalt of Emerald Lake were intruded along normal fault that cuts Buffalo Fork thrust fault.

Several major igneous intrusive bodies cut the Wiggins Formation or other Eocene igneous and volcaniclastic rocks in the Yellowstone-Absaroka volcanic area (Love and others, 1955; Smedes and Prostka, 1972). Three of these have been age dated, and all are older than Oligocene. For example, the Washakie Needles, a dacite body which cuts through the Wiggins Formation 8 miles $(13 \mathrm{~km})$ east of the principal reference section of the Wiggins (fig. 1, 8 miles east of loc. 6) has been dated by the fission-track method on sphene as $38.8 \pm 1.6$ m.y. (L. L. Love, 1972). A quartz monzonite dike that intruded the Wiggins Formation near Kirwin, 8 miles $(13 \mathrm{~km})$ northeast of the type Wiggins, has a potassium-argon age (biotite) of 40.2 \pm 1.4 m.y. (Schassberger, 1972). The Birch
Hills, a dacite intrusion 28 miles $(45 \mathrm{~km})$ west of Emerald Lake, has been dated by the fission-track method on apatite as $40.5 \pm 2.6$ m.y. (L. L. Love, 1972).

The available regional data on Oligocene rocks suggest that the Yellowstone-Absaroka volcanic area was not the source of major amounts of volcanic debris in Oligocene time and that the tuffs may have been airborne from volcanic centers many miles to the west, northwest, or southwest.

\section{COLTER FORMATION (MIOCENE)}

Five small poorly exposed outcrops of generally massive gray sandstone comprising the Colter formation (fig. 3) 
are present in the Emerald Lake area. The rocks are intensely fractured in places (figs. $3,13,15,16$, loc. SR), probably as a result of proximity to a large normal fault, in part post-early Miocene in age, that coincides with the trace of the Buffalo Fork thrust fault (fig. 3) of Laramide age. Because of this fracturing and the massive character of the sandstone, reliable bedding planes on which dips can be obtained are rare. This fact, coupled with covered intervals that may contain faults, makes any estimate of thickness uncertain. For example, if one assumes that the dip of $30^{\circ}$ (figs. 3,17 ) is a maximum, and (as is suggested along the White River-Colter contact to the southeast) the dip decreases to about $25^{\circ}$, a conservative figure of about 900 feet $(275 \mathrm{~m})$ in thickness seems reasonable. If, however, a dip of $30^{\circ}$ is present throughout the northwestern outcrop area, and there are no concealed faults, the

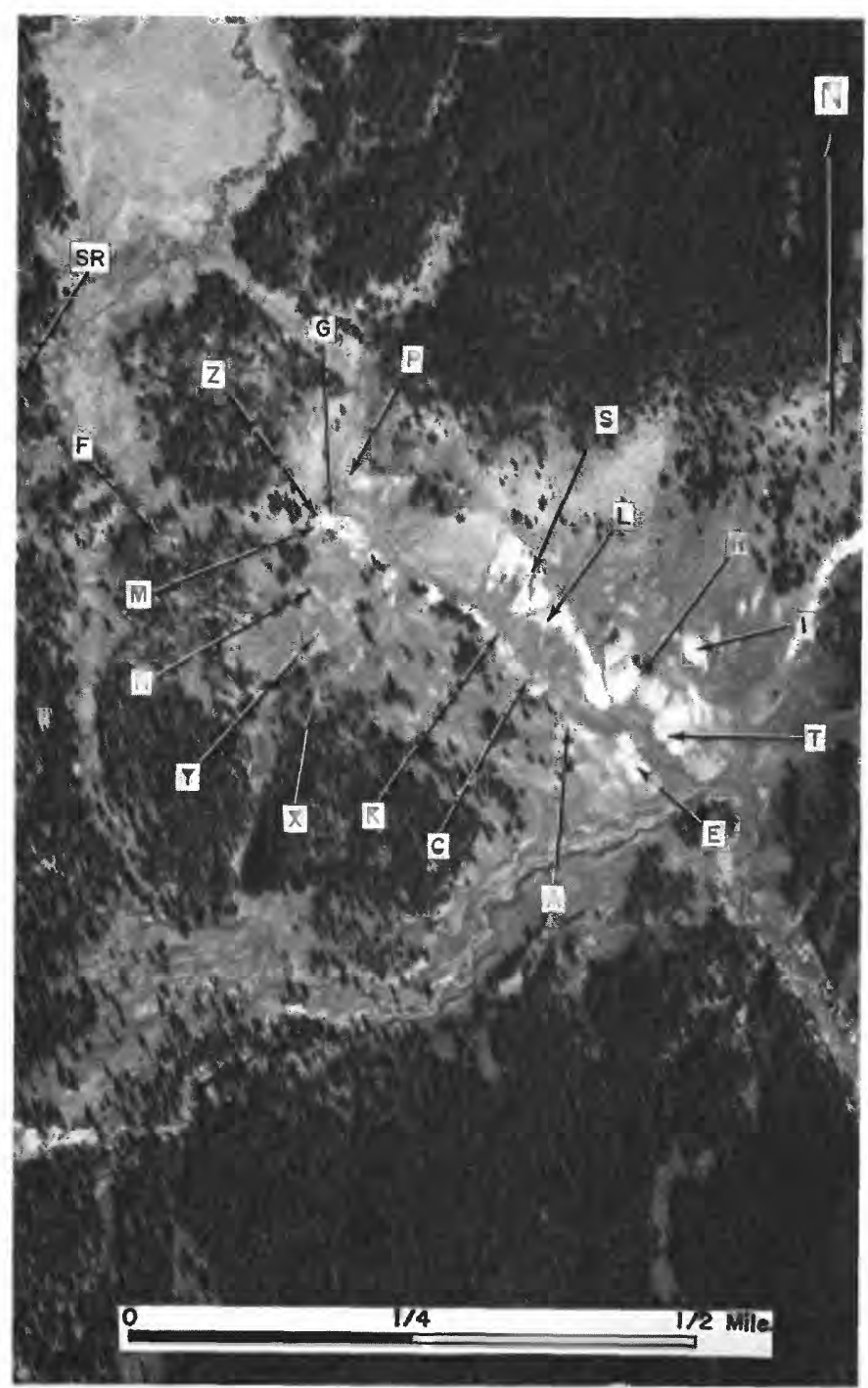

Figure 13.- Vertical aerial photograph showing sites where Oligocene and Miocene vertebrate fossils were collected at the Emerald Lake locality. Locality $E$ is the most productive site for Oligocene fossils and SR for Miocene. For fossil lists, see table 3. thickness could be 1,300 feet $(400 \mathrm{~m})$ or more.

No Miocene rocks are known in Yellowstone National Park, and those at the Emerald Lake locality have not previously been described except for one brief note (McKenna, 1972, p. 96).

The sandstone is remarkably homogeneous, almost entirely massive, and very fine grained. Very few claystone partings are present; those observed are cream colored and extremely fine grained. A few nodules of limy sandstone and irregular small masses of white secondary opal are present. About 30 percent of the rock is composed of tiny glass shards-some clear, others chalky white. The sandstone is poorly cemented. Black dendritic manganese oxide is common as are black speckles of manganese oxide in cavities or attached to pebbles. Some magnetite grains are present.

Subrounded granules and pebbles, as much as 1 inch $(2.5 \mathrm{~cm})$ in diameter, occur at a few horizons and are composed chiefly of purplish-gray and brown fine- to medium-grained andesite of the type found in the adjacent Wiggins Formation. Some highly rounded quartzite and chert pebbles, possibly reworked from the Harebell Formation of Late Cretaceous age, are present.

The paucity of bedding dips in the Colter Formation and the only suggestive bedding dips in the underlying White River Formation, as well as the poor exposures in the two places where formations can be seen more or less in contact, require generalized interpretations of stratigraphic and structural relations. The Colter appears to overlap across the White River Formation, but the presence or absence of an angular unconformity has not been determined. At the northernmost of the two localities where the contact is exposed, there seems to be considerable local contact relief.

The Miocene age of the Colter Formation in the Emerald Lake area is based on five specimens of the following four vertebrate taxa collected from the SR locality (figs. 3, 13, 17; table 3): Allomys cf. A. nitens, Archaeolagus cf. A. ennisianus, Promerycochoerus leidyi and an undescribed genus and species of aplodontid rodent cf. Meniscomys and Niglarodon sp. (fig. 18). All these forms occur in the John Day Formation of Oregon but have not been reported to be associated together at any one level in that sequence. Allomys has been reported from beneath the Picture Gorge Basalt, and Promerycochoerus leidyi from well above it. The occurrence in Oregon of Archaeolagus and the new aplodontid genus could be from either above or below the basalt. Evernden, Savage, Curtis, and James (1964, p. 181, KA 648) gave an age for the Picture Gorge Basalt of 25.3 m.y.

The Gering Formation of Nebraska (Evernden and others, 1964; Obradovich and others, 1973) has yielded ages ranging from $28.0 \pm 0.7$ m.y. to $25.6 \mathrm{~m}$.y. The $25.6-\mathrm{m}$.y. age was obtained from near the local base of the Gering, at 
Table 3.-Distribution by site of identified taxa from the White River Formation of early Oligocene (Chadronian) age (sites $A$ through $T$ ), and from the Colter Formation of early Miocene age (site $S R$ ) at the Emerald Lake locality

[Miscellaneous specimens not yet identifiable to taxon occur at all these localities and also at localities F, X, Y, and Z (fig. 13)]

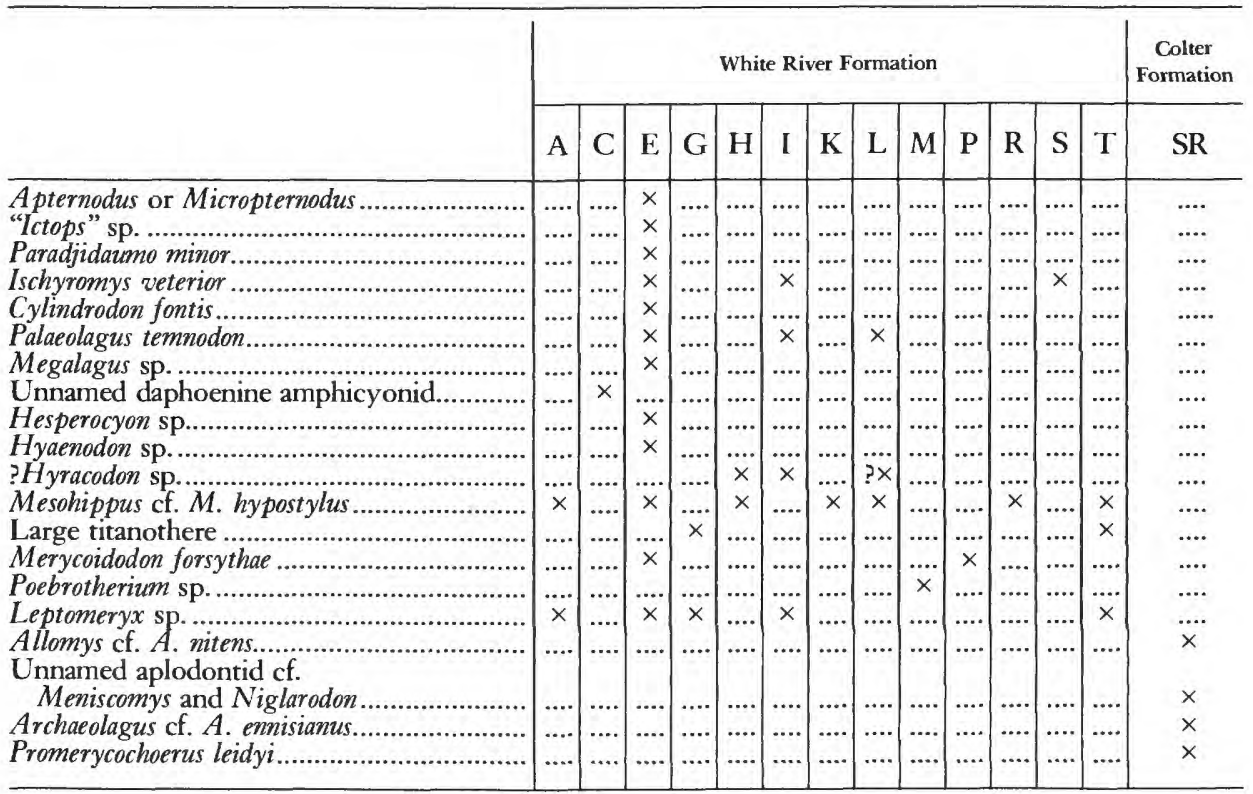

a site at Scotts Bluff National Monument, Nebr., where the Gering laps up onto the side of a paleovalley cut in older rocks (M. F. Skinner, oral commun., 1973). The 25.6-m.y. age, which was obtained from glass shards, is not necessarily anomalous on the grounds of its proximity to the local base of the Gering. Glass is somewhat unstable, and dates from it are regarded as suspect by many workers. The Gering is, at least in part, older than an ash in the Harrison Sandstone for which an age was obtained by Evernden, Savage, Curtis, and James (1964, p. 178, KA 481: 21.3 m.y.). No radiometric ages are available for the intervening Monroe Creek Sandstone, but it is more likely to be in the early part of the interval between these ages than in the later part because the Monroe Creek is separated from the overlying Harrison by a disconformity, whereas no conspicuous break exists between the Monroe Creek and the underlying Gering. The Colter Formation at the Emerald Lake locality is believed to be either in part an age equivalent to the Monroe Creek of Nebraska or perhaps still younger, although older than the Harrison.

The type Colter Formation, 18-20 miles (29-32 km) southwest of Emerald Lake (fig. 1, loc. 4), consists of about 7,000 feet $(2,140 \mathrm{~m})$ of mafic volcaniclastic rocks (Love, 1956a) that overlap strata ranging in age from Late Cretaceous to Oligocene. The finer grained beds are lithologically very similar to most of the Colter in the Emerald Lake locality. The following biostratigraphically useful vertebrate fossils were found about 4,150 feet $(1,270 \mathrm{~m})$ below the eroded top of the formation (Love, 1956a; Sutton and Black, 1972, p. 74-78) in the type section:
Proheteromys sp., Parahippus tyleri, Merychippus sp., Oxydactylus(?) sp., Merycochoerus sp., Brachycrus cf. $B$. rusticus, and Merychyus elegans (the last species was identified by Margaret Stevens, written commun., 1972). Sutton and Black considered the assemblage probably to be equivalent to that found in the Runningwater Formation of McKenna (1965) in Nebraska. Thus, the assemblage from the type Colter is somewhat younger than that from the Emerald Lake locality; however, this might be expected because the vertebrate fossils in the type Colter are about 2,800 feet $(850 \mathrm{~m})$ above the local base of the formation on Pilgrim Creek. Still higher in the Miocene time scale, possibly as young as Barstovian provincial age, is a vertebrate fossil assemblage from Cunningham Hill (fig. 1, loc. 5), possibly near the southern margin of the Miocene basin of deposition. The fossils occur about 1,000 feet $(300 \mathrm{~m})$ above the base of the Colter at that locality and consist of (Sutton and Black, 1972, p. 76-78): Scalopoides(?) sp., Hypolagus(?) sp., Pseudotheridomys sp., Miospermophilus sp., Proheteromys sp., Monosaulax sp., Plesiosminthus sp., Merychippus sp., Merycodus sp.

As mentioned earlier, no Miocene sedimentary or igneous rocks have yet been identified in Yellowstone National park, although 200 feet $(61 \mathrm{~m})$ or more of lightcolored soft sandstones and siltstones containing middle or late Miocene (late Hemingfordian or early Barstovian) vertebrate fossils have been reported (Horberg, 1940, p. 283-285; Wood and others, 1941; McKenna, 1955) along the Yellowstone River, from $20-25$ miles $(32-40 \mathrm{~km})$ north of the park (85-90 miles (137-145 km) north-northwest of Emerald Lake). 


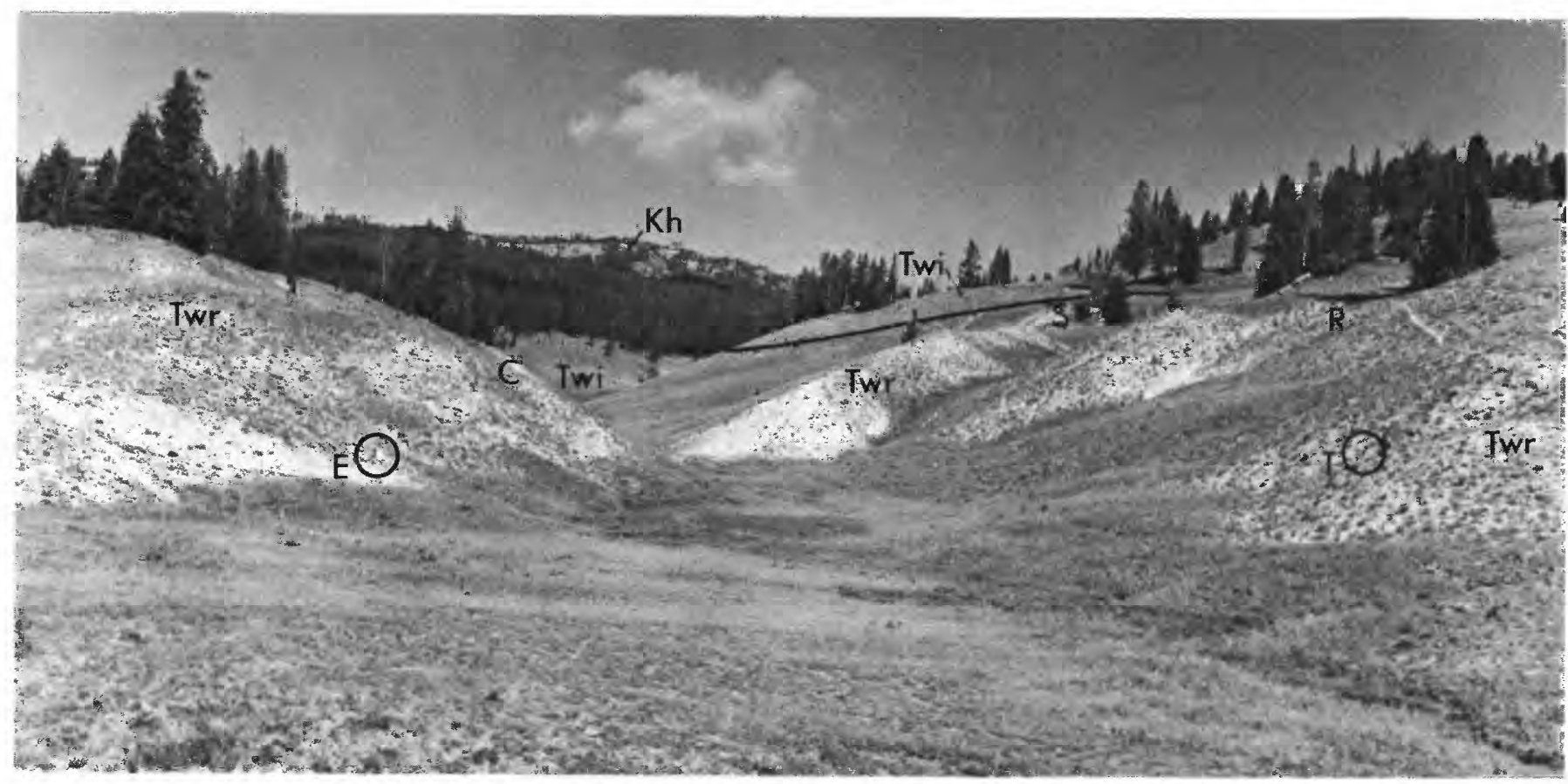

FIGURE 14.-View northwest up fault valley, showing vertebrate fossil sites and stratigraphic relations of formations. White beds of White River Formation (Twr) were deposited in steep-sided channel cut into volcanic conglomerate (Twi) of Wiggins Formation. Vertebrate fossil localities C, E, R, S, and T (fig. 13; table 3) are indicated. Men (circled) at localities E and T give scale. Harebell Formation (Kh) on far side of Buffalo Fork thrust fault is on Big Game Ridge along center skyline. Photograph by J. D. Love, Aug. 24, 1964.

The nearest Miocene rocks to the east of Emerald Lake are on the crest of the Bighorn Mountains, 160 miles (257 $\mathrm{km}$ ) away (McKenna and Love, 1972). The strata there are massive soft gray sandstones very similar to those at Emerald Lake and contain a vertebrate fossil assemblage that may be approximately contemporaneous with the Emerald Lake Miocene forms at site SR. It is older than that in the type Colter Formation.

The nearest Miocene rocks southeast of Emerald Lake are the Split Rock Formation of Love (1970) in the Granite Mountains area, 145 miles (235 km) away. No fossiliferous Miocene rocks are known at present in western Wyoming south of Jackson Hole, although there are some similar-appearing soft light-gray sandstones on Aspen Mountain (Love and Blackmon, 1962) south of Rock Springs, nearly 200 miles $(320 \mathrm{~km})$ from Emerald Lake.

\section{POST-MIOCENE ROCKS}

No post-Miocene sedimentary rocks are known in the Emerald Lake area, but there are two very different types of post-lower Miocene igneous rocks-one mafic, the other felsic. They are mentioned here because they provideclues as to the post-Colter geologic history of the area.

\section{PYROXENE ANDESITE AND BASALT OF EMERALD \\ LAKE}

Dark-gray, dull green, dark-red, and black pyroxene andesite and basalt, possibly of different ages but mapped together, are present in a linear zone along normal faults associated with the Buffalo Fork thrust trace (fig. 3) in and south of the Emerald Lake area. These rocks were first recognized by Iddings (in Hague and others, 1899, p. 300), who described them as follows:

A small hill on the divide between Fox Creek and Mink Creek is formed of a massive flow of pyroxene-andesite, which is jointed into great slabs and is thinly fissile in places. It resembles many occurrences of rhyolite. It is partly massive and vesicular, and is light gray with small phenocrysts of feldspar and pyroxene. It carries segregations of feldspar and pyroxene, and has cavities containing tridymite. Other portions of the same lava sheet are darker and denser ***. At the southern end of the valley of Fox Creek it is composed of fragments of basic andesite in a light-red matrix ****.

One of these outcrops is a dome-shaped ice-scoured hill of bedrock about 1,000 feet $(300 \mathrm{~m})$ north of Emerald Lake. The northern part of the hill is composed of massive lightgray coarse-grained andesite porphyry; the southern part is composed of the same kind of rock, but it is remarkably slabby. (See Iddings' description quoted above.) The slabs are $1-2$ inches $(2.5-5 \mathrm{~cm})$ thick. A potassium-argon wholerock age determination on one slab is $2.19 \pm 0.08 \mathrm{~m}$.y. (report by Teledyne Isotopes to M. C. McKenna, Nov. 25, 1970).

Most phenocrysts in the andesite porphyry are gray, green, or black. In some places the larger gray phenocrysts are granular and contain several minerals within the crystal outline. These have not been studied. Similar phenocrysts are as much as one-half inch $(1.3 \mathrm{~cm})$ in 
diameter in the walls of Mink Creek canyon, 2 miles (3.2 $\mathrm{km})$ south of the Emerald Lake area. About one-half mile $(0.8 \mathrm{~km})$ south-southeast of Emerald Lake is an outcrop of basalt which is black, dense, and heavy, with dark-green and black phenocrysts of pyroxene. At this locality the rock is shattered and is in vertical contact with Paleozoic rocks, indicating postbasalt movement on the fault.

The distribution pattern of the pyroxene andesite and basalt suggests that these rocks were intruded along zones of weakness related to the normal faults that developed on and near the Buffalo Fork thrust. Some of the normal faulting is apparently older than the andesite and basalt, whereas in a few places the basalt has been offset.

\section{HUCKLEBERRY RIDGE TUFF}

The Huckleberry Ridge Tuff is the post-Colter felsic volcanic rock in this area. It is a rhyolite welded tuff that flowed southeastward 15 miles $(25 \mathrm{~km})$ or more into the area from a caldera in central Yellowstone National Park (Christiansen and Blank, 1972). It is represented by a single downfaulted remnant about 2 miles $(3 \mathrm{~km})$ northnorthwest of the outcrops of the Colter Formation. As with the pyroxene andesite, the rhyolite has an age of about 2 m.y. on the basis of potassium-argon dating. Despite the coincidence in ages, the pyroxene andesite and rhyolite probably do not represent the same igneous event, for they originated in different areas with very different tectonic settings.

\section{STRUCTURAL SUMMARY}

The structural and depositional history of southern Yellowstone National Park has been summarized elsewhere (Love and Keefer, 1975), as has the history of the area to the west and southwest of the Emerald Lake area (Love

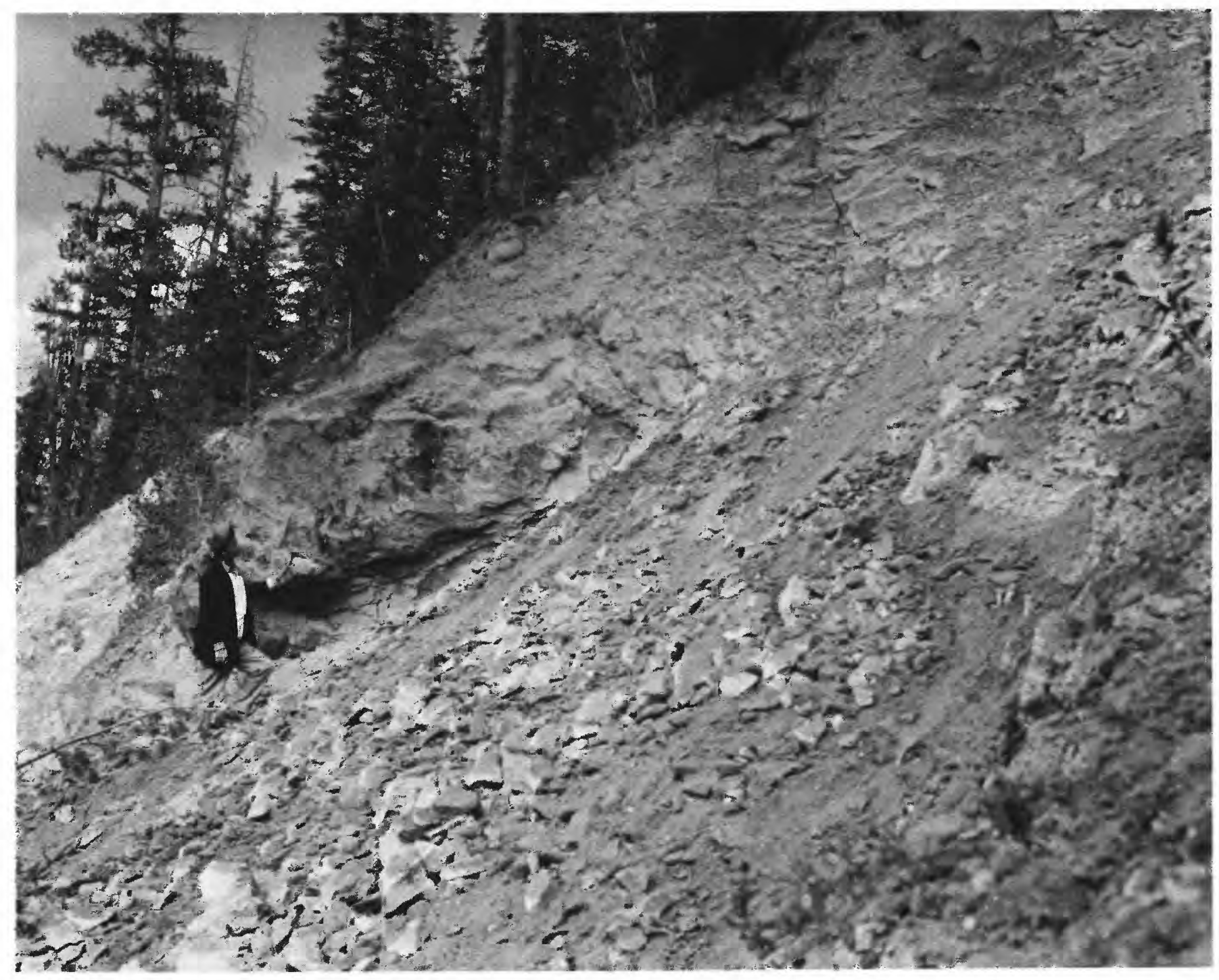

FIGURE 15.-Colter Formation at locality SR (fig. 13). Entire exposure is of massive very soft tuffaceous fine-grained gray sandstone, highly fractured because of proximity to a normal fault along trace of Buffalo Fork thrust (fig. 3). Photograph by J. D. Love, Aug. $27,1964$. 
and Reed, 1968; Love and others, 1973). Therefore, only the events directly related (or that were previously thought to be related) to the vertebrate fossil-bearing Oligocene and Miocene strata are given here.

Late middle or late Eocene.-Extensive volcanism occurred on and east of the Washakie Range. Giant mudflows and debris flows composing the Wiggins Formation extended west from the vent areas and buried the Washakie Range to a depth of several thousand feet. Large intrusive masses of dacite and quartz monzonite cut upward through the Wiggins Formation.

Late Eocene to Oligocene.-Before deposition of the White River Formation, 1,000 feet $(300 \mathrm{~m})$ or more of the Wiggins Formation was eroded away from the west margin of the Washakie Range. The direction of streamflow and the site of deposition of this large volume of clastic debris have not been determined. The fine-grained ashy material in the White River Formation was deposited in a west-trending steep-sided channel. Some of it was probably an ash fall, and the rest was water laid. The record of events between early Oligocene and early Miocene times is missing in the Emerald Lake area. There was apparently some erosion that left a rough topography on which the first Miocene strata were deposited.

Miocene.-During Miocene time a deep basin of deposition formed in Jackson Hole; the Emerald Lake area was probably near the northeast margin. It is not well known what the drainage patterns, source of sediments, and local topography were or how long sedimentation continued in the Emerald Lake area after early Miocene time.

Pliocene and Pleistocene.-After the Colter Formation

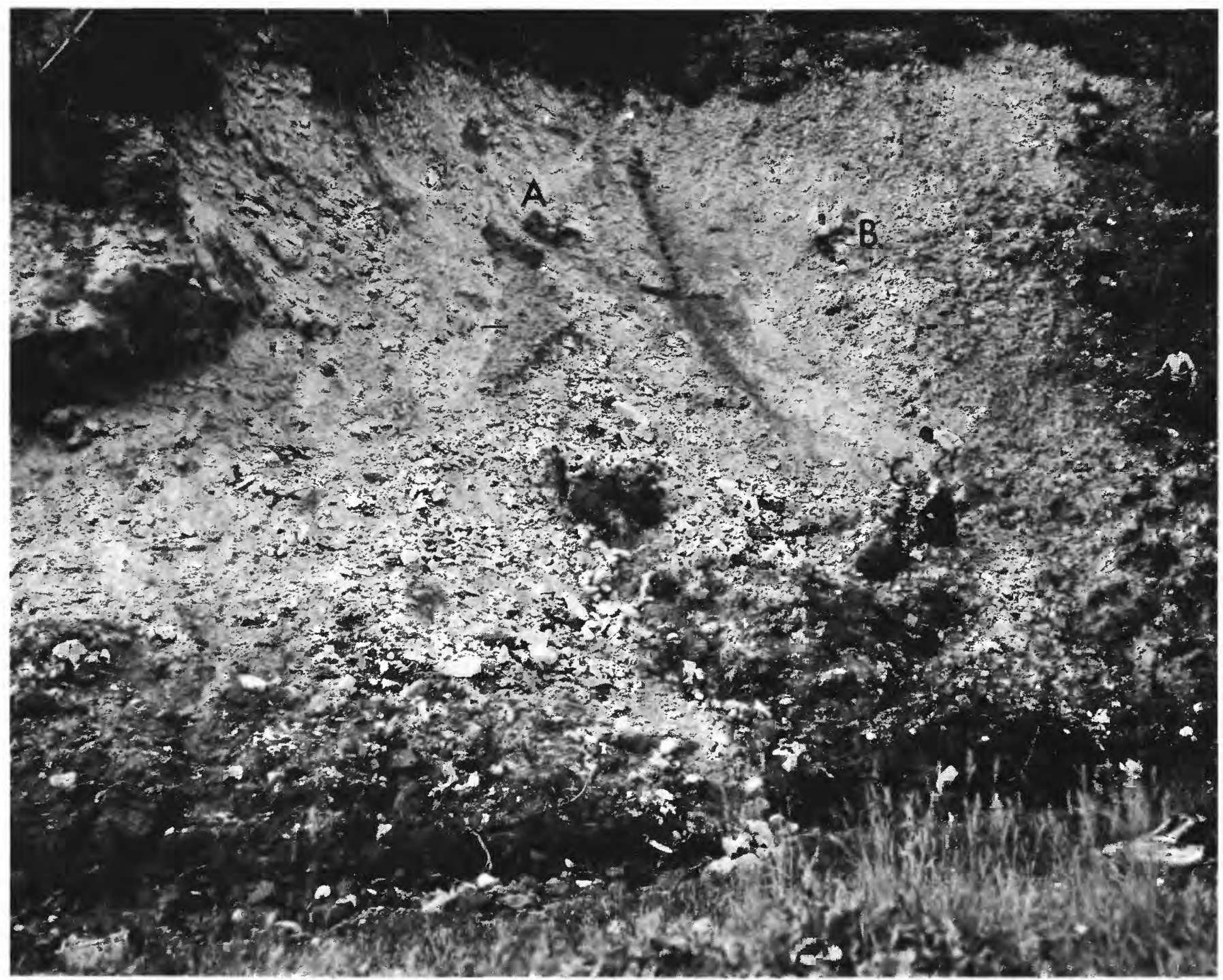

FIGURE 16.-View south at vertebrate fossil locality SR (fig. 13) in lower part of Colter Formation near head of Fox Creek. A, horizon of aplodontid rodent; B, probable horizon of oreodont Promerycochoerus leidyi, where bones were found in bedrock; C, site of talus block containing skull of Promerycochoerus leidyi. Note people at B and C for scale. Photograph by J. D. Love, Aug. 22, 1969. 


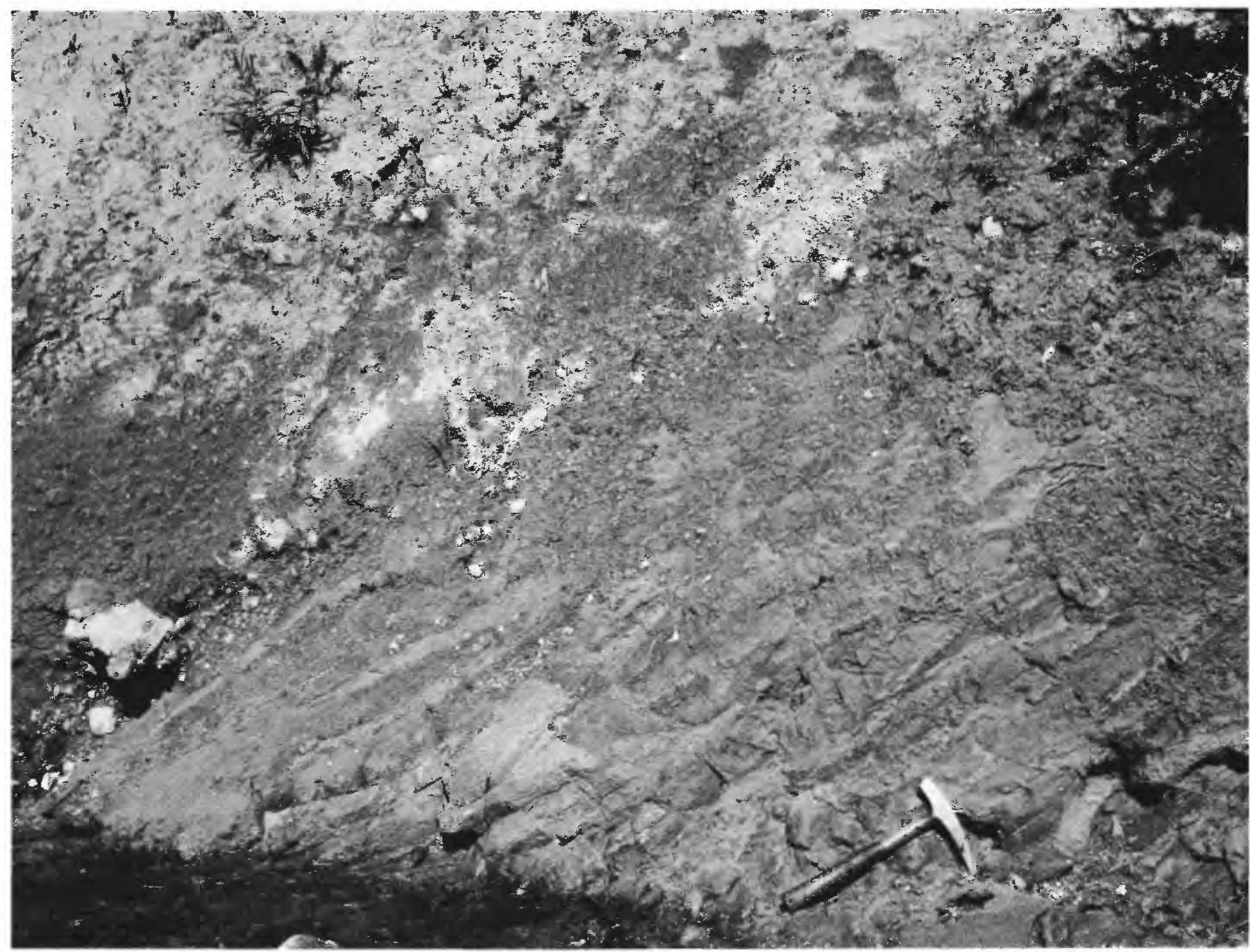

Figure 17.-Closeup view of west-dipping tuffaceous sandstone in upper part of Colter Formation near head of Fox Creek (at site of dip symbol in fig. 3). A thin lens of andesite and basalt pebble conglomerate, a rare occurrence, is shown at lower left margin. Photograph by J. D. Love, Aug. 22, 1969.

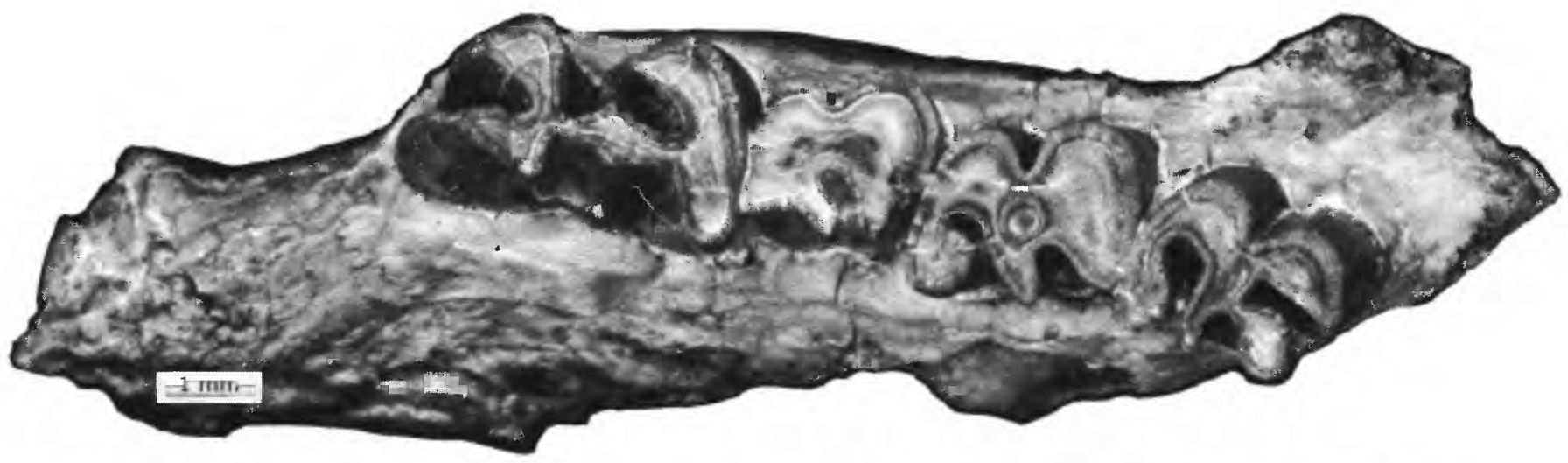

FIGURE 18.-Right lower jaw of undescribed aplodontid rodent related to Meniscomys and Niglarodon from locality SR (fig. 13). 
was deposited, a normal fault system developed along and near the trace of the Buffalo Fork thrust. The Washakie Range and the Tertiary strata that partially buried it were hinged down westward 1,500-2,000 feet (450-600 m), with the hinge line several miles east of the Emerald Lake area. Movement along the west margin of the downhinged block was distributed along several faults. The Wiggins Formation was downfaulted against the Madison Limestone in some places and against the Harebell in others. The timing of this normal faulting is not precisely known, but it is younger than the part of the Colter Formation exposed near Emerald Lake. Some faulting is younger than the 2-m.y.-old andesite and basalt and Huckleberry Ridge Tuff.

This episode of downfaulting is important because it was responsible for positioning the small soft remnants of Oligocene and Miocene rocks in such a way that they were protected from stream erosion and glaciation that completely removed the remainder of these strata from the adjacent region.

\section{REFERENCES CITED}

Black, C. C., 1968a, The Oligocene rodent Ischyromys and discussion of the family Ischyromyidae; Carnegie Mus. Annals, v. 39, art. 18, p. 273-305.

1968b, Small mammals from the Colter Formation, Jackson Hole, Wyoming, in Field Conf. Guidebook, Miocene in Wyoming and Colorado: Colorado Univ. Museum, p. 1-3.

1969, Fossil vertebrates from the late Eocene and Oligocene, Badwater Creek area, Wyoming, and some regional correlations, in Symposium on Tertiary rocks of Wyoming-Wyoming Geol. Assoc., 21st Field Conf., 1969, Guidebook: Casper, Wyo., Petroleum Inf., p. 43-47.

Christiansen, R. L., and Blank, H. R., Jr., 1972, Volcanic stratigraphy of the Quaternary rhyolite plateau in Yellowstone National Park: U.S. Geol. Survey Prof. Paper 729-B, 18 p.

Clark, John, Beerbower, J. R., and Kietzke, K. K., 1967, Oligocene sedimentation, stratigraphy, paleoecology, and paleoclimatology in the Big Badlands of South Dakota: Fieldiana-Geology Mem., v. $5,158 \mathrm{p}$.

Denson, N. M., and Gill, J. R., 1956, Uranium-bearing lignite and its relation to volcanic tuffs in eastern Montana and North and South Dakota, in Contributions to the geology of uranium and thorium by the United States Geological Survey and Atomic Energy Commission for the United Nations International Conference on Peaceful Uses of Atomic Energy, Geneva, Switzerland, 1955: U.S. Geol. Survey Prof. Paper 300, p. 413-418.

Emry, R. J., 1973, Stratigraphy and preliminary biostratigraphy of the Flagstaff Rim area, Natrona County, Wyoming: Smithsonian Contr. to Paleobiology, no. $18,43 \mathrm{p}$.

Evernden, J. F., Savage, D. E., Curtis, G. H., and James, G. T., 1964, Potassium-argon dates and the Cenozoic mammalian chronology of North America: Am Jour. Sci., v. 262, no. 2, p. 145-198.

Hague, Arnold, 1904, Atlas to accompany U.S. Geological Survey Monograph 32 on the geology of Yellowstone National Park: U.S. Geol. Survey.

Hague, Arnold, and others, 1899, Geology of the Yellowstone National Park: U.S. Geol. Survey Mon. 32, pt. 2, 893 p.
Harshman, E. N., 1972, Geology and uranium deposits,-Shirley Basin area, Wyoming: U.S. Geol. Survey Prof. Paper 745, 82 p.

Horberg, C. L., 1940, Geomorphic problems and glacial geology of the Yellowstone Valley, Park County, Montana: Jour. Geology, v. 48 , no. 3 , p. $275-303$.

Houston, R. S., 1964, The petrographic calendar, Pt. 3 of Nonpaleontological methods of correlation of rocks of Tertiary age in Wyoming: Wyoming Univ. Contr. Geology, v. 3, no. 1, p. 15-26.

Ketner, K. B., Keefer, W. R., Fisher, F. S., Smith, D. L., and Raabe, R. G., 1966, Mineral resources of the Stratified Primitive Area, Wyoming: U.S. Geol. Survey Bull. 1230-E, 56 p.

Love, J. D., 1939, Geology along the southern margin of the Absaroka Range, Wyoming: Geol. Soc. America Spec. Paper 20, 134 p.

1952, Preliminary report on uranium deposits in the Pumpkin Buttes area, Powder River Basin, Wyoming: U.S. Geol. Survey Circ. 176, 37 p.

1954a, Preliminary report on uranium in the Gas Hills area, Fremont and Natrona Counties, Wyoming: U.S. Geol. Survey Circ. 352, $11 \mathrm{p}$.

1956b, Cretaceous and Tertiary stratigraphy of the Jackson Hole area, northwestern Wyoming, in Wyoming Geol. Assoc. Guidebook 1lth Ann. Field Conf., 1956: p. 76-94.

1954b, Uranium in the Mayoworth area, Johnson County, Wyoming-A preliminary report: U.S. Geol. Survey Circ. 358, 7 p.

1956a, New geologic formation names in Jackson Hole, Teton County, northwestern Wyoming: Am. Assoc. Petroleum Geologists Bull., v. 40, no. 8, p. 1899-1914.

1956c, Geologic map of Teton County, Wyoming, in Wyoming Geol. Assoc. Guidebook 11th Ann. Field Conf., 1956: map in pocket.

1970, Cenozoic geology of the Granite Mountains area, central Wyoming: U.S. Geol. Survey Prof. Paper 495-C, 154 p.

1973, Preliminary geologic map of the Two Ocean Lake quadrangle, Teton County, Wyoming: U.S. Geol. Survey open-file map.

Love, J. D., and Blackmon, P. D., 1962, Alunite on Aspen Mountain, southwestern Wyoming, in Short papers in geology, hydrology, and topography: U.S. Geol. Survey Prof. Paper 450-D, p. D11-D15.

Love, J. D., and Keefer, W. R., 1975, Geology of sedimentary rocks in southern Yellowstone National Park, Wyoming: U.S. Geol. Survey Prof. Paper 729-D, 60 p.

Love, J. D., and Reed, J. C., Jr., 1968, Creation of the Teton landscape-The geologic story of Grand Teton National Park: Grand Teton Nat. History Assoc., 120 p.

Love, J. D., Reed, J. C., Jr., Christiansen, R. L., and Stacy, J. R. 1973, Geologic block diagram and tectonic history of the Teton region, Wyoming-Idaho: U.S. Geol. Survey Misc. Geol. Inv. Map I-730.

Love, J. D., Weitz, J. L., and Hose, R. K., 1955, Geologic map of Wyoming: U.S. Geol. Survey.

Love, L. L., 1972, The dacites of the Washakie Needles, Bunsen Peak, and the Birch Hills, Wyoming, and their relationship to the Absaroka-Gallatin volcanic province: Albuquerque, N. Mex., New Mexico Univ. unpub. M.S. thesis, open file, 86 p.

Mann, J. A., 1954, Geology of part of the Gravelly Range, Montana: Yellowstone-Bighorn Research Proj. Contr. 190, 92 p.

Mason, B. H., 1958, Principles of geochemistry, 2d ed.: New York, John Wiley \& Sons, $310 \mathrm{p}$.

McKenna, M. C., 1955, A new species of mylagaulid from the Chalk Cliffs local fauna, Montana: Washington Acad. Sci. Jour., v. 45, no. 4 , p. $107-110$.

1965, Stratigraphic nomenclature of the Miocene Hemingford Group, Nebraska: Am. Mus. Novitates, no. 2228, 21 p. 
1972, Vertebrate paleontology of the Togwotee Pass area, northwestern Wyoming, in West, R. M., coordinator, Guidebook-Field conference on Tertiary biostratigraphy of southern and western Wyoming, Aug. 5-10, 1972: Soc. Vertebrate Paleontologists, p. 80-101.

McKenna, M. C., and Love, J. D., 1972, High-level strata containing early Miocene mammals on the Bighorn Mountains, Wyoming: Am. Mus. Novitates no. 2490, $31 \mathrm{p}$.

Nelson, W. H., and Pierce, W. G., 1968, Wapiti Formation and Trout Peak Trachyandesite, northwestern Wyoming: U.S. Geol. Survey Bull. 1254-H, 11 p.

Obradovich, J. D., Izett, G. A., and Naeser, C. W., 1973, Radiometric ages of volcanic ash and pumice beds in the Gering Sandstone (earliest Miocene) of the Arikaree Group, southwestern Nebraska: Geol. Soc. America Abs. with Programs, v. 5, no. 6, p. 499-500.

Rohrer, W. L., and Obradovich, J. D., 1969, Age and stratigraphic relations of the Tepee Trail and Wiggins Formations, northwestern Wyoming, in Geological Survey research 1969: U.S. Geol. Survey Prof. Paper 650-B, p. B57-B62.
Schassberger, H. T., 1972, A K-Ar age of a quartz monzonite dike in the Kerwin (sic) Mining district, Park County, Wyoming: Isochron/West, no. 4, p. 31.

Shapiro, Leonard, and Brannock, W. W., 1956, Rapid analysis of silicate rocks: U.S. Geol. Survey Bull. 1036-C, p. 19-56.

Smedes, H. W., and Prostka, H. J., 1972, Stratigraphic framework of the Absaroka Volcanic Supergroup in the Yellowstone National Park region: U.S. Geol. Survey Prof. Paper 729-C, 33 p.

Sutton, J. F., and Black, C. C., 1972, Oligocene and Miocene deposits of Jackson Hole, Wyoming, in West, R. M., coordinator, Guidebook-Field conference on Tertiary biostratigraphy of southern and western Wyoming, Aug. 5-10, 1972: Soc. Vertebrate Paleontologists, p. 73-79.

Van Houten, F. B., 1964, Tertiary geology of the Beaver Rim area, Fremont and Natrona Counties, Wyoming: U.S. Geol. Survey Bull. 1164, 99 p. [1965].

Wood, H. E., and others, 1941, Nomenclature and correlation of the North American continental Tertiary: Geol. Soc. America Bull., v. 52 , no. 1 , p. $1-48$. 


\section{INDEX}

[Page numbers of major references are in italic]

A

Acknowledgments

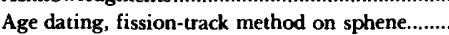
potassium-argon. See Potassium-argon ages.

\section{Allomys nitens}

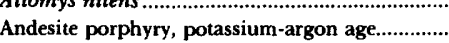
Aplodontid

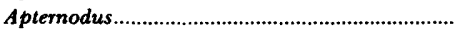

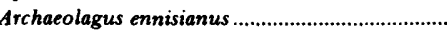

Artiodactyl, indet.

Aycross Formation, Duncan Ranch, potassium-

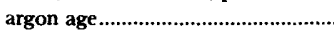

Badlands.........

Basalt, Emerald Lake area.

distribution pattern

Beaver Divide, White River Formation, analyses of tuffaceous strata.

Bighorn Mountains, strata along crest.

Black Butte, White River Formation, analyses of tuffaceous strata

Brachycrus rusticus..

brachyodon, Megalagus.

Buffalo Fork thrust, normal fault system ...............

Buffalo Fork thrust fault

Buffalo Fork thrust trace, basalt associated with. pyroxene andesite associated with

Chadronian provincial age...........................1, 13, 15, 17 Channel-fill deposit, White River Formation....... 19 Colter Formation, analyses of tuffaceous strata...

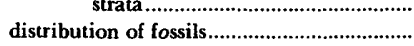

lithology...

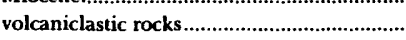

Cunningham Hill, Colter Formation, analyses of tuffaceous strata

Cylindrodon...............

font is ........................................................13, 14, 20

Dacite intrusive, Washakie Needles..

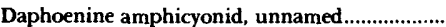

Domnina ...

Downfaulting, summary of structural significance

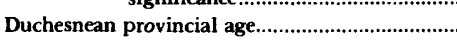

elegans, Merychyus.

Emerald Lake area, Colter and White River Formations, analyses of tuffaceous strata...

ennisianus, Archaeolagus.

19,20

Eocene rocks, late or late middle, structural summary........

potassium-argon ages

Wiggins Formation

Eutypomys sp.

Page
$A 2$
18
19,20
21
19,20
20
19,20
16
17


1
21
22
14
21
14
20
13
25
19
21
21

F

Faulting, obscuring stratigraphic relations between White River and Wiggins Formations

fontis, Cylindrodon.

forsythae, Merycoidodon.

Fossils, Allomys nitens

Apternodus.

Brachycrus rusticus

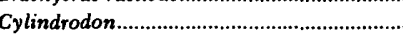

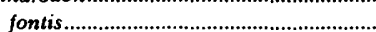

distribution in White River and Colter Formations

Domnina........

Eutypomys sp...

Hesperocyon sp.

Hyaenodon sp

Hypolagus sp.

Hyracodon sp.

Ictops sp.

Ischyromys parviden

pliacus.

typus...

veterior

Leptomeryx sp

Megalagus sp.... brachyodon

Meniscomys sp..

Merychippus sp...

Merychyus elegans

Merycochoerus sp.
Merycodus sp.......

Merycoidodon forsythae

Mesohippus hypostylus

Miocene.

stata

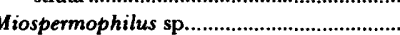

Monosaulax sp.....

new locality.....

Niglarodon sp

Oligocene....

Oxydactylus.

Palaeogale.

Palaeolagus...

$$
\text { lemnodon.... }
$$

Paradjidaumo minor

Parahippus tyleri

Parectypodus.

Plesiosminthus sp.

...................................

Proheteromys sp

Promerycochoerus leidyi

Pseudotheridomys sp.

Scalopoides sp....

Teleodus uintensis..

\section{G}

Geology of area, as mapped by Hague

Gering Formation, potassium-argon age.............. Scotts Bluff National Monument..

Granite Mountain, Split Rock Formation, analyses of tuffaceous strata
Page

H

Page

Harebell Formation ........................................... Al9, 25

Hesperocyon sp.................................................... 20

Huckleberry Ridge Tuff .........................................

Hyaenodon sp.......................................................

Hydracodont ........................................................ 16

Hypolagus sp......................................................

hypostylus, Mesohippus ...................................... 14, 20

Hyracodon sp...................................................... 20

I, J

Ictops sp...............................................................

Iddings, quoted, pyroxene andesite of Emerald Lake ................................ 21

Igneous intrusive bodies, in Wiggins For-

mation .............................................. 18

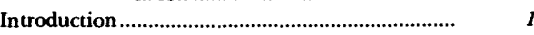

Ischyromys parvidens................................................

pliacus........................................................ 2, 2,13

typus........................................................... 2, 19

veterior ….................................................. 13, 20

John Day Formation ............................................

leidyi, Promerycochoerus...................................... 19, 20

Leptomeryx sp.

Lithology, basalt of Emerald Lake ........................

Colter Formation.......................................... 15, 20

Huckleberry Ridge Tuff ..................................

pyroxene andesite of Emerald Lake ...............

White River Formation ............................. 10, 11, 12

Wiggins Formation ...................................... 4, 4, 6, 9

$\mathbf{M}$

Madison Limestone, faulting

Megalagus brachyodon

Meniscomys sp.

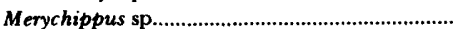

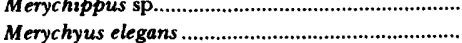

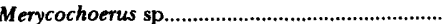

Merycodus sp. .

Merycoidodon forsythae....................................... 14, 20

Mesohippus hypostylus ............................................. 14, 20

Mink Creek locality ..............................................5, 6, 22

minor, Paradjidaumo ......................................... 14, 20

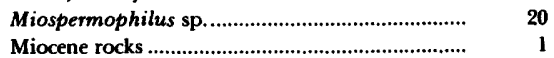

analyses of tuffaceous strata ............................ 14

Colter Formation ............................................. 18

crest of Bighorn Mountains ............................ 2

Split Rock Formation.......................................

structural summary........................................

Mount Hancock 15-minute quadrangle..................

Mudflows, Wiggins Formation ..............................

National Museum of Natural History, fossil specimens. 
Page

Niglarodon sp. nitens, Allomys

A19, 20 19,20

o

Oligocene rocks

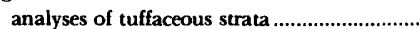

crest of Bighom Mountains

potassium-argon ages

structural summary.......

White River Formation

Oxydactylus sp.

$\mathbf{P}$

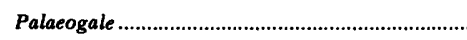
Palaeolagus.

cemnodon

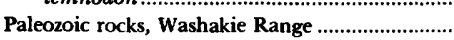

Paradjidaumo minor

Parahippus tyleri

Parectypodus

parvidens, Ischyromys

Phenocrysts, pyroxene

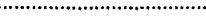

Picture Gorge Basalt.

Pleistocene rocks, structural summary

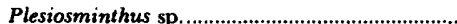

pliacus, Ischyromys

Pstructural summary

Poebrotherium sp.

Post-Miocene rocks.

Aycross Formation, Duncan Ranch

dacite intrusive.

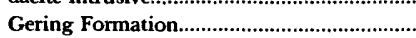

hornblende sample from Wiggins For mation

Huckleberry Ridge Tuff

Tepee Trail Formation, Badwater ...............

White River Formation

Wiggins Formation

Proheteromys sp

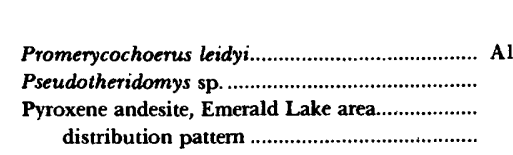

$\mathbf{R}, \mathbf{S}$

rusticus, Brachycrus...

Scalopoides sp.

Split Rock Formation, analyses of tuffaceous strata..

Miocene...

Stratigraphic relations, between White River and Wiggins Formations

Stratigraphic sections

White River Formation (part)

Wiggins Formation (part)

Structural summary

Tapir......

Tepee Trail Formation, Badwater.

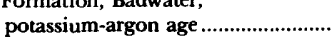

Teleodus uintensis. temnodon, Palaeolagus...........................................13, 14, 20 Thickness, White River Formation (part)............10, 11, 12

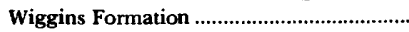
outcrops...

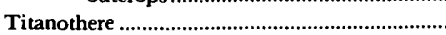

Two Ocean Lake, northeast, Colter Formation, analyses of tuffaceous strata

Two Ocean Lake quadrangle

tyleri, Parahippus

typus, Ischyromys

\section{U, V}

uintensis, Teleodus

2,13

veterior, Ischyromys

18,20

Volcanic debris, Yellowstone-Absaroka volcanic field...

20

20

18
Page

Washakie Needles, dacite intrusive Washakie Range, structural summary .................... 25

White River Formation, analyses of tuffaceous$$
\text { strata }
$$

Badwater, potassium-argon age ......................

Beaver Divide, potassium-argon age ...............

channel-fill deposit

distribution of fossils.........................................

East Beaver Divide, potassium-argon age......

Emerald Lake area, potassium-argon age.....

fossils.

Oligocene rocks

outcrops ...

part, lithology.

stratigraphic sections.

thickness

potassium-argon age.

relations to Wiggins Formation......................

semiquantitative spectrographic analyses......

unrecogaized remnant

Wiggins Formation, Castle Rock, potassiumargon ages

Eocene rocks

faulting

former age designation

igneous intrusive bodies

Mink Creek locality

outcrops

part, lithology.

stratigraphic sections

thickness .

potassium-argon age

tuffaceous rocks

volcanic conglomerates......................................

Wiggins Peak, potassium-argon age...............

Wood fragments, Wiggins Formation.

Yellowstone-Absaroka volcanic field

volcanic debris

Page

14

17

17

20
17

17

15

15

12

10

11,12

8,13

7
13

17

2

25

2, 16

18

$5,6,22$

4

9

, 12

9

2,7

2 